\title{
Food restriction-induced changes in gonadotropin-inhibiting hormone cells are associated with changes in sexual motivation and food hoarding, but not sexual performance and food intake
}

\section{Candice M. Klingerman ${ }^{1+}$, Wilbur P. Williams $I I I^{2+}{ }^{+}$, Jessica Simberlund ${ }^{1}$, Nina Brahme $^{2}$, Ankita Prasad $^{2}$, Jill E. Schneider ${ }^{1 *}$ and Lance J. Kriegsfeld ${ }^{2}$}

${ }^{1}$ Department of Biological Sciences, Lehigh University, Bethlehem, PA, USA

${ }^{2}$ Department of Psychology, Helen Wills Neuroscience Institute, University of California, Berkeley, CA, USA

\section{Edited by:}

Carol F. Elias, University of Texas

Southwestern Medical Center, USA

Reviewed by:

Jeremy T. Smith, Monash University, Australia

Barbara Woodside, Concordia

University, Canada

Jens D. Mikkelsen, University

Hospital Rigshospitalet, Denmark

*Correspondence:

Jill E. Schneider, Department of

Biological Sciences, Lehigh

University, 111 Research Drive,

Bethlehem, PA 18015, USA.

e-mail: jsOv@lehigh.edu

${ }^{+}$Candice M. Klingerman and Wilbur P. Williams III have contributed equally to this work.

${ }^{+}$Candice M. Klingerman and Wilbur P. Williams III are the Co-first authors.
We hypothesized that putative anorectic and orexigenic peptides control the motivation to engage in either ingestive or sex behaviors, and these peptides function to optimize reproductive success in environments where energy fluctuates. Here, the putative orexigenic peptide, gonadotropin-inhibiting hormone $(\mathrm{GnIH}$, also known as RFamide-related peptide3 ), and the putative anorectic hormones leptin, insulin, and estradiol were examined during the course of food restriction. Groups of female Syrian hamsters were restricted to $75 \%$ of their ad libitum food intake or fed ad libitum for 4,8 , or 12 days. Two other groups were food-restricted for 12 days and then re-fed ad libitum for 4 or 8 days. After testing for sex and ingestive behavior, blood was sampled and assayed for peripheral hormones. Brains were immunohistochemically double-labeled for $\mathrm{GnlH}$ and the protein product of the immediate early gene, c-fos, a marker of cellular activation. Food hoarding, the number of double-labeled cells, and the percent of $\mathrm{GnIH-Ir}$ cells labeled with Fos-Ir were significantly increased at 8 and 12 days after the start of food restriction. Vaginal scent marking and $\mathrm{GnIH-Ir} \mathrm{cell} \mathrm{number} \mathrm{significantly} \mathrm{decreased} \mathrm{after} \mathrm{the} \mathrm{same} \mathrm{duration} \mathrm{of} \mathrm{restriction.} \mathrm{Food}$ hoarding, but not food intake, was significantly positively correlated with cellular activation in $\mathrm{GnIH-Ir}$ cells. Vaginal scent marking was significantly negatively correlated with cellular activation in $\mathrm{GnIH}-\mathrm{Ir}$ cells. There were no significant effects of food restriction on plasma insulin, leptin, estradiol, or progesterone concentrations. In the dorsomedial hypothalamus $(\mathrm{DMH})$ of energetically challenged females, strong projections from NPY-Ir cells were found in close apposition to $\mathrm{GnlH}$-Ir cells. Together these results are consistent with the idea that metabolic signals influence sexual and ingestive motivation via NPY fibers that project to $\mathrm{GnIH}$ cells in the DMH.

Keywords: appetitive behavior, estradiol, ingestive behavior, leptin, neuropeptide Y, progesterone, RFamide-related peptide-3, sex behavior

\section{INTRODUCTION}

Metabolic control of the reproductive system has been demonstrated in every order of the class Mammalia (Bronson, 1989). Reproduction is inhibited when the availability of oxidizable fuels is scarce, and reproduction is rapidly stimulated when fuels become abundant (Bronson, 1986; Szymanski et al., 2007). Mechanisms that measure fuel availability and modulate reproductive processes serve to optimize reproductive success in environments where food availability and energy demands fluctuate (Bronson, 1989; Wade and Schneider, 1992; Schneider, 2006). The mechanisms that switch behavioral priorities from ingestive to reproductive behaviors might occur at multiple loci, including effects on behavioral motivation (the internal desire for food or sex), performance (mating and eating) and the hypothalamic-pituitary-gonadal (HPG) system, including the gonadotropin releasing-hormone $(\mathrm{GnRH})$ pulse generator, pituitary gonadotropin secretion, and ovarian steroid secretion. Despite action at multiple loci, the majority of research has focused on metabolic challenges that induce anestrus, inhibit gonadotropin secretion, and stimulate food intake (Kalra et al., 1988; I'anson et al., 1991; McShane et al., 1992; Wade and Schneider, 1992; Foster et al., 1998; Henry et al., 1999; Cunningham, 2004; Schneider, 2004). Food deprivation and other metabolic challenges inhibit pulsatile GnRH secretion which, in turn, prevents pituitary luteinizing hormone ( $\mathrm{LH}$ ) secretion, ovarian steroid synthesis and secretion, and ovarian-steroid-dependent copulatory behavior in a wide variety of species, including Syrian hamsters (McClure, 1962; Morin, 1975; Ronnekleiv et al., 1978; Bronson and Marsteller, 1985; Foster and Olster, 1985; Armstrong and Britt, 1987; Bronson, 1988; Sprangers and Piacsek, 1988; Schneider and Wade, 1989; Thomas et al., 1990; Cameron, 1996; Shahab et al., 1997, 2006; Temple et al., 2002; Terry et al., 2005). 
It is likely, however, that energy deficits influence behavioral motivation even before metabolic challenges become so severe that they induce anestrus. We have used female Syrian hamsters (Mesocricetus auratus). Lean Syrian hamsters become anestrus after a 48-h period of food deprivation, whereas pre-fattened Syrian hamsters, which do not become anestrus, show deficits in paracopulatory behaviors. Fattened Syrian hamsters food-deprived for 24-36 h show significantly decreased appetitive sex behaviors, such as decreased vaginal scent marking, and significantly increased appetitive ingestive behaviors, such as food hoarding (Schneider et al., 2007). Appetitive behaviors bring animals in contact with the goal object (mating partners or food), and often occur separated in time from mating and eating (Sherrington, 1906; Craig, 1917; Lorenz, 1950; Johnston, 1974, 1977; Lisk et al., 1983; Everitt, 1990). Syrian hamster appetitive sex behaviors include vaginal scent marking, an estradiol-dependent behavior that occurs with increasing frequency over days 1,2, and 3 of the 4-day estrous cycle (with day 4 being proestrus; Johnston, 1977). In addition, appetite for food and sex can be assessed in this species by measuring the preference for males vs. food (the time spent with the male minus the time spent with food divided by the total time). Consummatory sex behavior is commonly measured in Syrian hamsters as the incidence of the lordosis reflex, a posture that allows male intromission on day 4 of the estrous cycle and requires proestrus concentrations of plasma estradiol and progesterone, tactile flank stimulation, and male olfactory cues (Lisk et al., 1983). Flank marking is yet another appetitive social behavior, more specifically, an agonistic behavior, that is higher in dominant female hamsters, increases with increases in plasma estradiol concentrations, and is inhibited at the time of estrus by the presence of adult male hamsters (Albers and Rawls, 1989; Albers and Rowland, 1989). With regard to ingestive behaviors, food hoarding is an example of appetitive behavior, whereas food intake is a consummatory behavior in Syrian hamsters (Smith and Ross, 1950; Waddell, 1951).

Consummatory sex and ingestive behavior can be simultaneously stimulated under special circumstances (Kaplan et al., 1992). Appetitive behaviors, however, are often in conflict, and females must choose between engaging in courtship or foraging for food. In nature, females typically have a choice between ingestive and sex behavior, and the decision can impact survival and reproductive success. Thus, we have included appetitive behaviors and the choice between food and males in our experiments. By attention to the decisions to engage in either reproductive or ingestive behavior, we hoped to gain insight into hormones and neuropeptides implicated in control of food intake and reproduction, such as gonadotropin-inhibiting hormone $(\mathrm{GnIH})$, neuropeptide $\mathrm{Y}(\mathrm{NPY})$, leptin, insulin, estradiol, and progesterone.

In this experiment, appetitive and consummatory sex and ingestive behaviors were examined over the course of food restriction to test the following hypotheses: (1) Appetitive behaviors are more sensitive than consummatory behaviors to the effects of mild food restriction, (2) changes in appetitive behavior are correlated with increases in neural activation in cells that contain $\mathrm{GnIH}$, and (3) cells that contain NPY project to the vicinity of GnIH cells in the dorsomedial hypothalamus (DMH). GnIH and NPY were examined for the following reasons.
Gonadotropin-inhibiting hormone has been implicated in environmental control of reproduction and food intake. GnIH was first identified from quail hypothalamus. Treatment with the newly identified peptide inhibited gonadotropin release from pituitary cells in vitro in a dose-dependent manner, and hence it was named GnIH (Tsutsui et al., 2000). Orthologous neuropeptides were subsequently discovered in a wide range of vertebrate species (reviewed in Bentley et al., 2010; Kriegsfeld et al., 2010; Smith and Clarke, 2010; Tsutsui et al., 2010). Evidence has accumulated that the mammalian homolog of $\mathrm{GnIH}$, RFamide-related peptide-3 (RFRP-3, Arg-Phe-NH2 in the C terminus), acts as a negative regulator of gonadotropin secretion in all species investigated, including hamsters, mice, rats, cattle, sheep, non-human primates, and human beings (Kriegsfeld et al., 2006; Johnson et al., 2007; Clarke et al., 2008; Anderson et al., 2009; Smith and Clarke, 2010). In the past 5 years, the accumulated evidence across many mammalian species has revealed many similarities among mammals and birds in the function of the orthologous peptides, and there is general consensus that "GnIH" is the appropriate nomenclature for both peptides. It is unlikely, however, that inhibition of gonadotropin secretion is the only function of this peptide.

We hypothesize that $\mathrm{GnIH}$ is a modulator of sex and ingestive motivation in Syrian hamsters because intracerebroventricular treatment with $\mathrm{GnIH}$ disrupts sex behavior of female whitecrowned sparrows and male rats (Bentley et al., 2006; Johnson et al., 2007), and increases food intake in male rats (Johnson et al., 2007), sheep, mice, and monkeys (Clarke, personal communication). GnIH cells in Syrian hamsters are restricted to the $\mathrm{DMH}$, contain estradiol receptors (ER), and show neural activation in response to increased circulating concentrations of estradiol (Kriegsfeld et al., 2006). If GnIH is important for the effects of mild food restriction on motivation, increases in cellular activation of $\mathrm{GnIH}$-immunoreactive (Ir) cells would be predicted to precede or coincide with increases in ingestive motivation and decreases in sexual motivation. Our hypothesis would be refuted if there were no increase in cellular activation in GnIH-Ir cells or if activation occurred too late to account for changes in behavior. Thus, the present experiments examined cellular activation in $\mathrm{GnIH}$-Ir cells and appetitive sex and ingestive behavior after either $0,4,8$, or 12 days of $25 \%$ food restriction or after 4 or 8 days of ad libitum feeding to females previously food-restricted for 12 days.

Neuropeptide Y is a hormone that has long been studied in relation to energy balance and reproduction, and more recently, NPY has been implicated in appetitive aspects of ingestion. NPY gene expression is increased in discrete nuclei of the hypothalamus, including the $\mathrm{DMH}$, in response to energy restriction in rodents, including Syrian hamsters (Brady et al., 1990; Jones et al., 2004). Intracerebroventricular treatment with NPY rapidly increases food intake and suppresses mating behavior of male and female rodents, including Syrian hamsters (Clark et al., 1985; Stanley and Leibowitz, 1985; Kulkosky et al., 1988; Corp et al., 2001; Jones et al., 2004), and some data are consistent with the idea that appetitive aspects of behavior are more sensitive to NPY than consummatory aspects of behavior (Ammar et al., 2000). Most relevant to the present study, food hoarding is increased by treatment with NPY agonists and decreased by treatment with antagonists to specific NPY receptors in Siberian hamsters (Day et al., 2005). 
Investigators interested in NPY effects on food hoarding have focused on the paraventricular nucleus $(\mathrm{PVH})$ and arcuate nucleus (Arc) of the hypothalamus and the perifornical area, but not the DMH. Thus, we double-labeled for GnIH-Ir and NPY-Ir to determine whether there are NPY projections to the GnIH cells in the DMH. In addition, we measured plasma levels of progesterone, leptin, insulin, and estradiol because they are putative orexigenic agents and anorectic hormones implicated in control of energy balance and reproduction in a number of species including Syrian hamsters (Wade et al., 1991; Ahima et al., 1996; Schneider et al., 1998; Eckel, 2004; Klingerman et al., 2010). These hormones and neuropeptides had not been measured at different durations after mild food restriction and re-feeding and in relation to changes in $\mathrm{GnIH}$ prior to these experiments.

\section{MATERIALS AND METHODS}

All subjects were adult (60-90 days of age), female Syrian hamsters obtained from Charles River Breeding Laboratories (Wilmington, MA, USA). Upon arrival, hamsters were housed singly in opaque, Nalgene cages $(31 \mathrm{~cm} \times 19 \mathrm{~cm} \times 18 \mathrm{~cm})$ in a room maintained at $23 \pm 1^{\circ} \mathrm{C}$ with a $14: 10$ light-dark cycle (lights on at $2200 \mathrm{~h}$ ). Hamsters were fed Harlan Rodent Chow 2016 and water was available at all times. All procedures were conducted according to the National Institutes of Health Guide for the Care and Use of Laboratory Animals, the United States Department of Agriculture, and a protocol approved by the Lehigh University Institutional Animal Care and Use Committee.

\section{EXPERIMENT 1: EFFECTS OF ENERGY RESTRICTION ON BEHAVIOR, GnIH, AND CIRCULATING HORMONES}

This experiment was designed to examine cellular activation in $\mathrm{GnIH}$ cells and circulating hormones after testing for appetitive and consummatory sex and ingestive behaviors in animals subject to mild food restriction for varying durations.

\section{Preference apparatus}

Hamsters were acclimated, trained, and tested in a preference apparatus designed to duplicate aspects of their native habitat, and to allow quantification of behaviors associated with the motivation to engage in either sex or ingestive behavior (Schneider et al., 2007). Hamsters in the wild live in isolation in underground burrows from which they emerge for only $90 \mathrm{~min}$ per day at dawn and dusk, and spend virtually every minute of this time foraging for and hoarding food (Gattermann et al., 2008). Matings have been observed only at the entrance to the female burrow. Together, these considerations suggest that decisions about whether to engage in ingestive or sex behaviors that occur near the burrow entrance during the 90-min above-ground foraging period are relevant to their reproductive success. Thus, each preference apparatus consisted of a home cage for the subject female connected via a vertical tube to two boxes: One with an adult male hamster (male box) and another box containing a food source (food box). Home cages were made from opaque, Nalgene cages $(31 \mathrm{~cm} \times 19 \mathrm{~cm} \times 18 \mathrm{~cm})$ lined with fine wood shavings with a door that was kept closed when the animals were not being trained or tested. The vertical tube was $134 \mathrm{~cm}$ in length and was connected to tubes in a T-configuration that were 40$50 \mathrm{~cm}$ in length. The food box contained a weighed amount
$(150 \pm 5 \mathrm{~g})$ of hoardable pellets made from standard laboratory chow (Harlan Rodent Chow 2016) that was broken into $2 \mathrm{~cm}$ pieces, a size that permits pouching and enables hamsters with full cheek pouches to fit readily through the tubes. The male boxes for the stimulus hamsters were made from clear, Plexiglas cages $(27 \mathrm{~cm} \times 20 \mathrm{~cm} \times 15 \mathrm{~cm})$ with wire barriers that allowed auditory, olfactory, and visual interaction, but prevented mating or fighting. The stimulus male boxes did not contain food or water.

Females were acclimated to the home cage for $24 \mathrm{~h} /$ day for at least 1 week prior to testing, which reduced any tendencies to sleep, move bedding, or hoard food into any other compartments during later preference testing. After acclimation to the home, females were trained to expect access to the food and male boxes at the onset of the dark period. Hamsters experienced training sessions with the food source box once a day for 2 days on days 1 and 2 of the estrous cycle, and training sessions with the male box once a day for 2 days on days 3 and 4 of the estrous cycle. Training is described in detail in two previous publications (Klingerman et al., 2010, 2011).

Females that showed at least two consecutive estrous cycles and had been acclimated and trained in the preference apparatus were first tested for baseline behaviors including food hoarding, vaginal scent marking, flank marking, and male preference calculated as (time spent with the male - time spent with food)/total time.

During baseline testing, $24 \mathrm{~h}$ food intake was measured for at least 4 days prior to the start of the experiment to obtain a 4-day average daily intake. The $25 \%$ food-restricted females were given $75 \%$ of their baseline daily intake by giving a pre-weighed food ration immediately after behavior testing, approximately $2 \mathrm{~h}$ after the onset of the dark phase of the light-dark cycle. For all foodrestricted females, restriction started on day 4 of the estrous cycle, and all females were sacrificed on day 4 of a subsequent cycle. This level of food restriction was chosen because previous experiments showed that $25 \%$ food restriction for up to 16 days does not induce anestrus (Klingerman et al., 2010, 2011).

After baseline testing, the 48 hamsters were randomly placed into one of six groups that did not differ significantly in body weight $(115-175 \mathrm{~g})$. The groups included hamsters that were foodrestricted by $25 \%$ (fed $75 \%$ of ad libitum food intake determined during baseline) for 4 days $(n=6)$, food-restricted for 8 days $(n=6)$, food-restricted for 12 days $(n=12)$, food-restricted for 12 days and re-fed ad libitum for 4 days $(n=6)$, food-restricted for 12 days and re-fed ad libitum for 8 days $(n=6)$, or fed ad libitum $(n=12)$.

Testing began at the onset of the dark phase of the photoperiod $(1200 \mathrm{~h})$ on day 3 and was conducted under dim, red illumination. The door to the home cage was opened and females were allowed access to both the male and food boxes for a total of $90 \mathrm{~min}$. During the first $15 \mathrm{~min}$, vaginal marking, flank marking, food hoarding and eating as well as location (male, food, or home cage) were recorded. After $15 \mathrm{~min}$ of observation, the experimenter stopped recording and the test continued for an additional $75 \mathrm{~min}$ ( 90 min total); i.e., the females continued to have access to both the male and food boxes. After the 90-min test was complete, the hamsters were returned to their respective cages and the doors to the home cages were closed. Weight of food in the home cage and 
food box was measured and recorded to determine the amount of food hoarded and eaten during the 90-min test.

\section{Blood collection and perfusion}

Female hamsters were tested in the preference apparatus on day 3 of the estrous cycle, and at the same time the next day, they were euthanized and a terminal blood sample was taken. Plasma was assayed for estradiol and progesterone concentrations to determine effects of food restriction, and to determine whether levels were below those that would induce lordosis. Plasma insulin and leptin concentrations were assayed to determine the effects of chronic restriction. In order to avoid the confounding effects of meals and cephalic phase hormone release, both food-restricted and ad libitum-fed animals were given access to the amount of food normally fed to the food-restricted females for $15 \mathrm{~min} 4 \mathrm{~h}$ before blood collection. This schedule was chosen because previous results showed that Syrian hamsters do not show post-fast hyperphagia, and plasma insulin and leptin concentrations are not significantly increased in Syrian hamsters until more than $4 \mathrm{~h}$ after a meal (Schneider et al., 2000). Thus, plasma hormone concentrations in our different groups of females would be expected to reflect length of food restriction rather than effects of meals. All hamsters were sacrificed before the onset of the dark phase of the photoperiod $(1200 \mathrm{~h})$ by an overdose of sodium pentobarbital (Ovation Pharmaceuticals, Inc., Deerfield, IL, USA). Blood was centrifuged at $3000 \mathrm{rpm}$ and $5^{\circ} \mathrm{C}$ for $20 \mathrm{~min}$. Plasma was collected and frozen at $-20^{\circ} \mathrm{C}$ until analysis.

Animals were perfused intracardially with phosphate buffered saline (PBS, pH 7.4 at $4^{\circ} \mathrm{C}$ ) followed by $4 \%$ paraformaldehyde in PBS at the same temperature. Brains were removed, post-fixed for $24 \mathrm{~h}$ at $4^{\circ} \mathrm{C}$ in $4 \%$ paraformaldehyde, and stored at $4^{\circ} \mathrm{C}$ in $20 \%$ sucrose and $0.001 \%$ thimerosal until sectioning. All brains were sectioned within 30 days using a freezing microtome set at $40 \mu \mathrm{m}$. Hypothalamic brain sections were placed into polyvinyl pyrrolidone (PVP) and stored at $-20^{\circ} \mathrm{C}$ until immunohistochemical staining.

\section{Immunohistochemistry}

Cellular activation in GnIH-containing cells was measured by double-labeling for intranuclear Fos, the product of the immediate-early gene, $c$-fos, a well established marker of changes in cellular activity in response to stimuli in rodents (Hoffman et al., 1993). Tissue was collected and every fourth $40 \mu \mathrm{m}$ section was double-labeled using fluorescence immunohistochemistry. Fos (1:50,000; Jackson ImmunoResearch Laboratories, West Grove, PA, USA) was amplified with biotinylated tyramine $(0.6 \%)$ for $30 \mathrm{~min}$ at room temperature prior to incubation in CY-2 conjugated streptavidin (1:200; Jackson ImmunoResearch Laboratories) for $1 \mathrm{~h}$. Following labeling for Fos, sections were labeled using an antibody directed against GnIH specifically for Syrian hamsters (1:10,000; PAC 1365), with CY-3 donkey anti-rabbit (1:200) as the secondary antibody/fluorophore. The antibody has been extensively characterized in this species and has been shown to be specific to $\mathrm{GnIH}$ with no cross-reactivity with related RFamide peptides (Gibson et al., 2008).

The population of GnIH-expressing cells is restricted to the DMH in Syrian hamsters, unlike in sheep, birds, and other rodents
(Kriegsfeld, 2006; Kriegsfeld et al., 2006, 2010). In addition, we typically find a few scattered peri-DMH cells in Syrian hamsters. We used standard procedures for dual-label immunofluorescence to count all double-labeled cells in Syrian hamster sections that contained the DMH (see below under Light and Confocal Microscopy).

The mean number of GnIH cells was obtained by counting the number of cells that were labeled by the GnIH antibody in each animal, taking the sum of all GnIH labeled cells for each experimental group, and dividing by the sample size of the group. The percent of GnIH cells that were also labeled for Fos was calculated for each animal by counting the number of double-labeled cells, dividing by the total number of GnIH cells (the sum of the Fos-labeled plus the non-labeled GnIH cells), and multiplying by 100.

\section{Light microscopy}

Brain sections processed for immunocytochemistry were mounted and coverslipped and were investigated using a Zeiss Z1 microscope. Sections were examined using the standard wavelengths for CY-2 $(488 \mathrm{~nm})$ and CY-3 $(568 \mathrm{~nm})$. Every fourth section through the $\mathrm{DMH}$ was assessed, and those areas expressing $\mathrm{GnIH}$ Ir were recorded for coexpression with Fos protein using confocal microscopy (see below). For light microscopy, areas identified as having double-labeled cells were digitally captured at $200 \times$ in 8 bit grayscale using a cooled CCD camera (Zeiss). The total number of GnIH cells and the percentage of cells expressing Fos were recorded by two independent observers blind to the experimental conditions.

\section{Confocal microscopy}

Cells characterized as double-labeled with Fos/GnIH at the conventional microscopy level were confirmed with confocal microscopy to ensure that Fos was expressed within the cells rather than in overlapping cells in the same field of view. Likewise, cells classified as single-labeled were assessed to ensure that the conventional microscopy strategy did not result in false negatives. At least $10 \%$ of those cells quantified using conventional microscopy were assessed in confocal scans for Fos co-labeling. Regions of the brain with putative double-label identified at the light level were scanned at $400 \times$ using confocal microscopy. Cells were observed under a Zeiss Axiovert 100TV fluorescence microscope (Carl Zeiss, Thornwood, NY, USA) with a Zeiss LSM 510 laser scanning confocal attachment. The sections were excited with an Argon-Krypton laser using the standard excitation wavelengths for CY-2 and CY-3. Stacked images were collected as $1.0 \mu \mathrm{m}$ multitract optical sections. Using the LSM 3.95 software (Zeiss), red and green images of the sections were superimposed. GnIH cells in the $\mathrm{DMH}$ were examined through their entirety in $1.0 \mu \mathrm{m}$ steps. Each microscope channel (i.e., CY-2 and CY-3) was excited independently in the same focal plane, and the photographs were merged into a single red-green image (because in fluorescence confocal microscopy, two fluorescent channels cannot be viewed simultaneously). The software program, Adobe Photoshop, was used to turn individual channels on (illuminated) and off independently, in order to confirm double-labeling of individual cells. First, we identified cells with a visibly stained nucleus in the GnIH channel, 
and then, when the other channel was illuminated, noted those in which Fos-staining cells filled the void. This procedure greatly reduced the potential for counting false positives compared to dual-label quantification performed using two chromogens.

To examine NPY contacts, GnIH-Ir cells with putative NPY contacts were scanned though the extent of each cell in $0.5 \mu \mathrm{m}$ increments. Cells characterized as double-labeled with NPY/GnIH at the conventional microscopy level were confirmed with confocal microscopy to ensure that Fos was expressed within the cells rather than in overlapping cells in the same field of view. Likewise, cells classified as single-labeled were assessed to ensure that the conventional microscopy strategy did not result in false negatives. Only those cells in which the NPY- labeled fiber contacted a GnIH-Ir cell in the same $0.5 \mu \mathrm{m}$ scan were counted as close contacts.

\section{Leptin and insulin radioimmunoassay}

Blood plasma was analyzed for leptin using the Multi-Species Leptin Radioimmunoassay (RIA) kit (Millipore, St. Charles, MO, USA). Samples were run in duplicate in the same assay with assay limits between $1.0 \mathrm{ng} / \mathrm{ml}$ and $50 \mathrm{ng} / \mathrm{ml}$. Similarly, plasma insulin was measured in duplicate using a Rat Insulin RIA kit (Millipore, St. Charles, MO, USA) adjusted to use $50 \mu$ l of plasma with assay limits between 0.01 and $10.0 \mathrm{ng} / \mathrm{ml}$. Insulin and leptin assays were performed by Millipore Biomarker Services (St. Charles, MO, USA).

\section{Estradiol and progesterone radioimmunoassay}

Blood plasma was analyzed for estradiol and progesterone using RIAs (TKE21 and TKPG2, Siemens Medical Solutions Diagnostics, Los Angeles, CA, USA). Assay limits were between 10.0 and $1035.4 \mathrm{pg} / \mathrm{ml}$ for the estradiol assay and 0.09 and $13.0 \mathrm{ng} / \mathrm{ml}$ for the progesterone assay. For progesterone values to fall within the acceptable range, blood plasma was diluted 1:10 prior to analysis. Estradiol and progesterone assays were conducted by the University of Virginia Center for Research in Reproduction Ligand Assay and Analysis Core (Charlottesville, VA, USA).

\section{Statistical analysis}

Behavioral, hormonal, and immunohistochemical data were analyzed using one-way analysis of variance (ANOVA) with different durations of food restriction as the main effect. In order to meet the assumption of homogeneity of variances, some behavioral scores were $\log (x+1)$ transformed prior to the ANOVA (Sokal and Rohlf, 1969). This applied to food hoarding, male preference, and flank marking. $F \max _{(5,4)}$ for those variables after log transformation were $4.8,11.72$, and 12.9 respectively, showing that there were no significant differences among the variances of the transformed scores. Means and SE of the means of the raw, untransformed scores appear in all figures for ease of presentation. When main effects were significant, post hoc comparisons were made using Duncan's Multiple Range test. Correlation coefficients were calculated to determine whether there was a significant association between cellular activation in GnIH cells and each behavior variable, or between plasma hormone concentrations and each behavioral variable. Differences were considered statistically significant if $P<0.05$.

\section{EXPERIMENT 2: EFFECTS OF FOOD DEPRIVATION AND BODY FAT CONTENT ON CELLULAR ACTIVATION IN GnIH CELLS AND NPY PROJECTIONS TO THE DMH}

These two experiments examined cellular activation in $\mathrm{GnIH}$ cells in the DMH that were either susceptible to or buffered from severe metabolic challenges (food deprivation). Previous work determined that adult, estrous-cycling hamsters below $120 \mathrm{~g}$ in body weight were highly likely to show anestrus after $48 \mathrm{~h}$ or more of food deprivation, whereas those above $125 \mathrm{~g}$ were buffered from the effects of food deprivation due to their higher body fat content and the ability to oxidize free fatty acids from lipids stored in adipose tissue (Schneider and Wade, 1989).

Hamsters that were the same age, with the same diet composition, were created by feeding diets that differed in the energy required to ingest them. The low body weight group was fed four pellets (approximately $20 \mathrm{~g}$ ) of standard rodent chow in the wire hopper that hangs into the ceiling of the cage. The high body weight group was fed powdered rodent chow ad libitum on the floor of the cage. The former group showed a high level of activity as they stood upright and gnawed at the pellets. The latter group, those fed the powdered chow, expended comparably less energy and gained body weight faster because they were not required to chew their food in order to consume it, and they slept in close proximity, if not right in the food.

In the first experiment, Experiment 2A, hamsters were either high $(n=5,133.13 \pm 2.9 \mathrm{~g})$ or low body weight $(n=6$, $113.6 \pm 3.5 \mathrm{~g}$ ) and half of each group was fed ad libitum or fooddeprived for $72 \mathrm{~h}$ ending on day 4 of the estrous cycle, the day of the LH surge and ovulation. This experiment was designed to determine whether cellular activation in GnIH cells on the day of the LH surge would be affected by the severe energetic challenge known to induce anestrus, and whether having a high body fat content prior to deprivation would buffer this effect. LH assays were performed by The University of Virginia Ligand Assay and Analysis Core Laboratory Services using the Rat Sandwich-IRMA assay. Two-way ANOVA, with food availability and prior body weight as the two main factors, was used to analyze the data.

The second experiment, Experiment 2B, was designed to examine cellular activation in $\mathrm{GnIH}$ cells earlier, in the follicular phase, during the initiation of effects of food restriction on the $\mathrm{GnRH}$ pulse generator. Thus, 18 hamsters of a high $(n=9,121.2 \pm 2 \mathrm{~g})$ or low body weight $(n=9,104.2 \pm 3.1 \mathrm{~g})$ were food-deprived for either $36 \mathrm{~h}$ (euthanized on day 2 of the estrous cycle) or $50 \mathrm{~h}$ (euthanized on day 3 of the cycle). An additional group $(n=6,131.4 \pm 2.5)$ served as ad libitum-fed controls and data were analyzed with a one-way ANOVA.

In both experiments, the blood was sampled and assayed for LH, and hamsters perfused as described for Experiment 1. Animals were perfused intracardially with $\mathrm{PBS}\left(\mathrm{pH} 7.4\right.$ at $4^{\circ} \mathrm{C}$ ) followed by $4 \%$ paraformaldehyde in $\mathrm{PBS}$ at the same temperature. Brains were removed, post-fixed for $24 \mathrm{~h}$ at $4^{\circ} \mathrm{C}$ in $4 \%$ paraformaldehyde, and stored at $4^{\circ} \mathrm{C}$ in $20 \%$ sucrose and $0.001 \%$ thimerosal until sectioning. All brains were sectioned within 30 days using a freezing microtome set at $40 \mu \mathrm{m}$. Hypothalamic brain sections were placed into PVP and stored at $-20^{\circ} \mathrm{C}$ until staining.

Double-labeling for Fos and $\mathrm{GnIH}$ and double-labeling for NPY and GnIH was carried out as described in Experiment 1 
on every fourth section. NPY fibers were immunostained using an NPY antibody, rabbit polyclonal anti-NPY (1:10,000; Santa Cruz Biotechnology, Inc., Santa Cruz, CA, USA), and was amplified with biotinylated tyramine $(0.6 \%)$ for $30 \mathrm{~min}$ at room temperature prior to incubation in CY-2 conjugated streptavidin (1:200; Jackson ImmunoResearch Laboratories) for $1 \mathrm{~h}$. Following labeling for NPY, sections were labeled using an antibody directed against $\mathrm{GnIH}$ specifically for Syrian hamsters (1:10,000; PAC 1365), with CY-3 donkey anti-rabbit (1:200) as the secondary antibody/fluorophore.

\section{RESULTS}

\section{EXPERIMENT 1: DIFFERENT DURATIONS OF FOOD RESTRICTION, GnIH AND BEHAVIOR Ingestive behaviors}

One-way ANOVA showed a significant main effect of food availability on the amount of food hoarded $[F(5,42)=2.64, P<0.04]$ as well as on the $\log (x+1)$ transform of the amount of food hoarded $[F(5,42)=5.42, P<0.02$; Figure 1, top]. Similarly, when the amount of food hoarded post-restriction was subtracted from baseline food hoarded, there was a significant effect of food restriction on the change in the amount of food hoarded $[F(5,42)=2.75$, $P<0.03$ ]. Post hoc tests showed that the amount of food hoarded was significantly higher in the 8-day and 12-day food-restricted groups compared to the ad libitum-fed group and the 4-day food-restricted group $(P<0.05)$.

There was a significant main effect of food availability on the amount of time spent eating during the preference test $[F(5,42)=7.56, P<0.0001$; Table 1]. Hamsters spent significantly more time eating after 4,8 , and 12 days of food restriction compared to hamsters fed ad libitum ( $P<0.05$; Table 1).

The amount of food eaten ( $\mathrm{g}$ ) during the 90-min test (Figure 2C) did not differ significantly among groups fed ad libitum or food-restricted for varying durations.

\section{Reproductive behaviors}

The effect of food availability on the number of vaginal scent marks per $15 \mathrm{~min}$ was significant $[F(5,42)=4.66, P<0.002$; Figure 1, bottom]. Hamsters food-restricted for 8 and 12 days showed significantly fewer vaginal scent marks than those fed ad libitum and those food-restricted for only 4 days $(P<0.05)$, but those re-fed for 4 and 8 days still showed significantly fewer vaginal scent marks than those fed ad libitum $(P<0.05)$.

The effect of food availability on the number of flank marks was significant $[F(5,42)=3.48, P<0.01]$ as was the $\log (x+1)$ transform of flank marking $[F(5,42)=4.7, P<0.002]$. The number of flank marks in 4-day food-restricted females was significantly higher than that of females fed ad libitum $(P<0.05)$, but the flank marking scores of hamsters in the other groups were not significantly higher than those of hamsters fed ad libitum (Table 1).

Male preference was calculated as (the amount of time females spent with a male - the amount of time spent with food)/the total time in the preference apparatus (Table 1). There was a main effect of food restriction on male preference $[F(5,40)=3.81 ; P<0.007]$. There was a main effect of food restriction on the $\log (x+1)$ transform of male preference $[F(5,40)=3.44 ; P<0.01]$. Post hoc

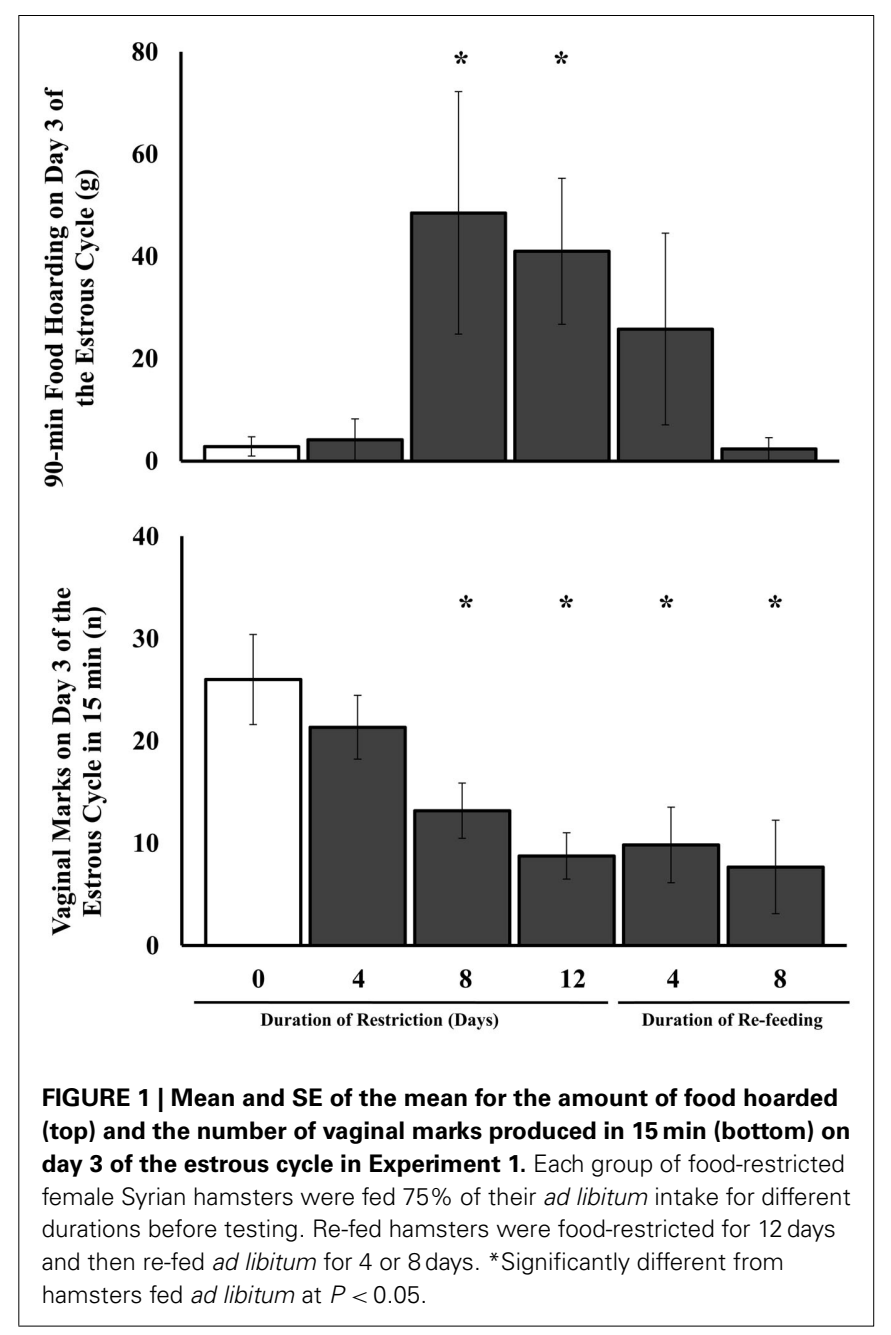

analysis showed that 12-day restricted hamsters had significantly lower male preference than ad libitum-fed female hamsters.

\section{Body weight}

When the hamsters' final body weights were subtracted from initial body weights, the groups differed significantly in the amount of body weight lost $[F(5,42)=30.92, P<0.0001$; Figure $2 \mathrm{~A}]$.

Body weights among the groups were not significantly different at the start of the experiment. The effect of duration of food restriction on final body weight was significant $[F(5,42)=4.37$, $P<0.003$; Figure 2B]. Body weights were significantly decreased starting at 4 days after the start of food restriction $(P<0.05)$ compared to hamsters fed ad libitum. Hamsters fed ad libitum throughout the experiment were significantly heavier compared to all other groups except hamsters food-restricted for 12 days and re-fed ad libitum for 8 days (Figure 2B).

\section{GnIH immunoreactivity and cellular activation}

Cellular activation in GnIH-Ir cells was calculated as (the number of cells double-labeled for Fos-Ir and GnIH-Ir/the total number of GnIH-Ir cells) $\times 100$. There was a significant main effect of food availability on cellular activation in GnIH-Ir cells 


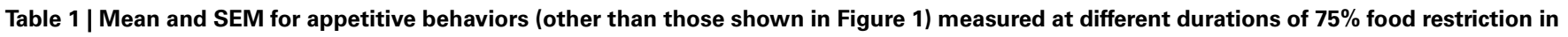
female Syrian hamsters provided with a choice between food and a male hamster.

\begin{tabular}{|c|c|c|c|c|c|c|}
\hline & \multicolumn{4}{|c|}{ Duration of food restriction (days) } & \multicolumn{2}{|c|}{ Duration of re-feeding } \\
\hline & 0 (Ad libitum) & 4 & 8 & 12 & 4 & 8 \\
\hline Time spent eating (s) & $24.6 \pm 6.9$ & $226.7 \pm 59.4^{*}$ & $225.8 \pm 57.6^{*}$ & $263.8 \pm 48.7^{*}$ & $79.2 \pm 36.2$ & $36.7 \pm 20.9$ \\
\hline Time spent hoarding (s) & $0 \pm 0$ & $0 \pm 0$ & $35.0 \pm 35.0$ & $12.5 \pm 6.2$ & $72.5 \pm 64.8$ & $20.8 \pm 20.8$ \\
\hline Flank marks $(n)$ & $2.4 \pm 1.5$ & $7.5 \pm 2.1^{*}$ & $2.5 \pm 1.3$ & $0.3 \pm 0.3$ & $0 \pm 0$ & $0.2 \pm 0.2$ \\
\hline $\begin{array}{l}\text { Male preference (time with male-time } \\
\text { with food)/total time }\end{array}$ & $0.31 \pm 0.10$ & $0.23 \pm 0.13$ & $0.04 \pm 0.16$ & $-0.08 \pm 0.10$ & $-0.12 \pm 0.10$ & $0.22 \pm 0.21$ \\
\hline
\end{tabular}

${ }^{*}$ Significantly different from time 0 at $P<0.05$.
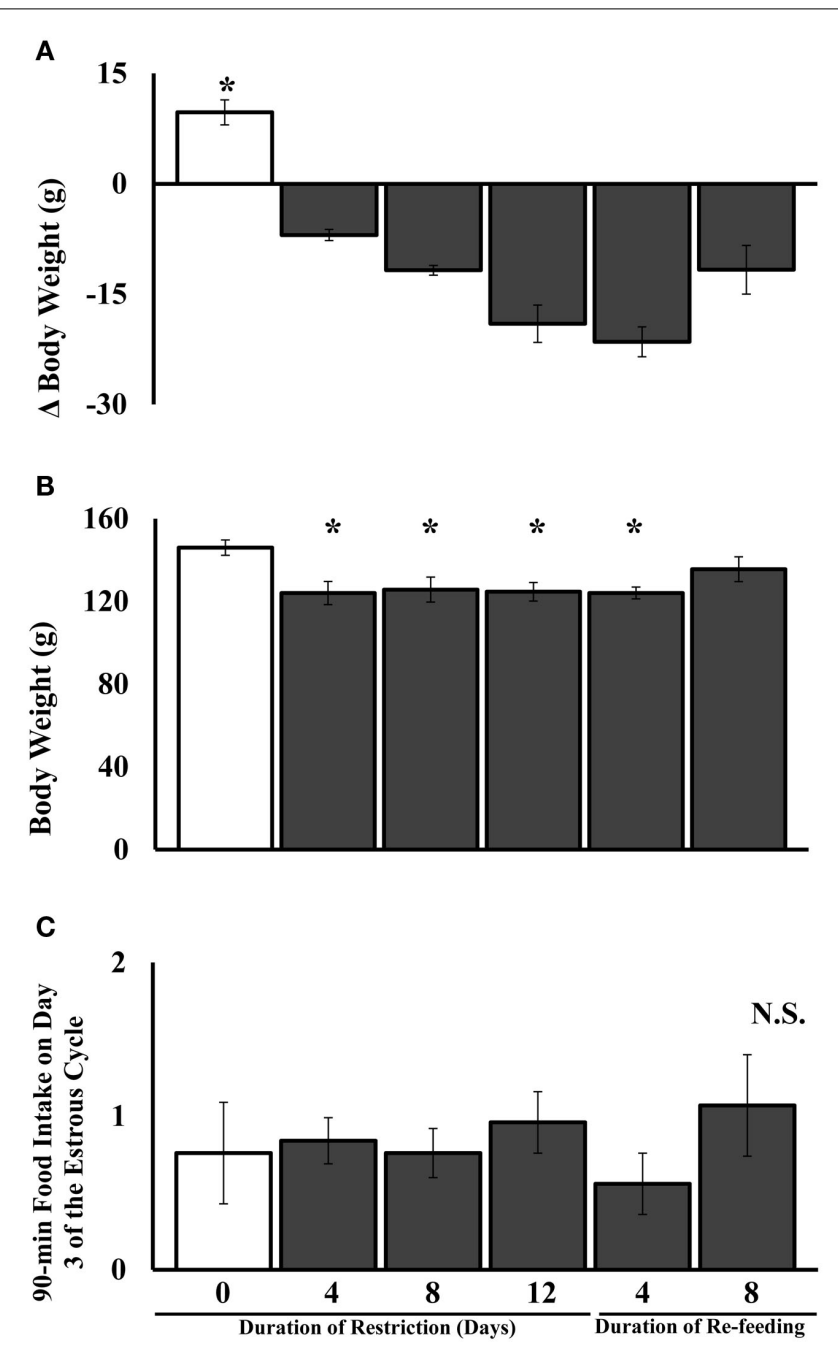

FIGURE 2 | Mean and SE of the mean for (A). body weight change, (B) final body weight, and (C) 90-min food intake of female Syrian hamsters either fed ad libitum or food-restricted to $75 \%$ of their ad libitum intake for 4,8 , or 12 days or food-restricted for 12 days and then re-fed for 4 or 8 days in Experiment 1. * Significantly different from ad libitum at $P<0.05$.

$[F(5,38)=3.47, P<0.01$; Figure 3A $]$. Post hoc analysis revealed a significant increase in cellular activation in GnIH-Ir cells at 8 and 12 days of food restriction compared to hamsters fed ad libitum $(P<0.05)$.
There was a significant effect of food restriction on the total number of GnIH-Ir cells $[F(5,38)=2.88, P<0.03]$, with a significant decrease in the number of $\mathrm{GnIH}$ cells that were immunoreactive in the females food-restricted for 8 and 12 days compared to those fed ad libitum and those food-restricted for 4 days $(P<0.05$; Figure 3B).

There was a significant main effect of food restriction on the absolute number of double-labeled Fos-Ir/GnIH-Ir cells $[F(5,38)=2.457, P<0.05]$. Post hoc analysis showed significant increases in the number of double-labeled cells 4 and 8 days after restriction $(P<0.05$; Figure $3 \mathrm{C})$.

\section{Plasma leptin, insulin, estradiol, and progesterone concentrations}

There was a significant main effect of food treatment on plasma leptin concentrations $[F(5,41)=2.50, P<0.05$; Figure 4]. Post hoc comparisons revealed that plasma leptin concentrations did not differ between ad libitum-fed and food-restricted females after any level of food restriction. However, females food-restricted for 12 days and re-fed ad libitum for 4 days had significantly higher plasma leptin concentrations compared to females fed ad libitum. The effect of food restriction or re-feeding on plasma insulin, progesterone, or estradiol concentrations were not significant (Figure 4).

\section{Correlations}

Changes in food hoarding during food restriction (Figure 1, top) showed a striking resemblance to changes in cellular activation in GnIH-Ir cells (Figure 3A). There was a significant positive correlation between the amount of food hoarded and percent of GnIH-Ir cells that were positive for Fos-Ir $(r=0.585 ; P<0.0001)$, and a significant negative correlation between food hoarded and GnIH-Ir cell count $(r=0.436 ; P<0.003)$. The amount of food hoarded was significantly correlated with body weight loss $(r=0.368$; $P<0.01$ ), but not with raw body weight. The correlations between food hoarding and other variables were not statistically significant (body weight, leptin, insulin, estradiol, or progesterone concentrations).

There was a significant negative correlation between time spent eating and body weight $(r=0.437 ; P<0.002)$. The correlations between time spent eating and other variables were not statistically significant (change in body weight, number of GnIH-Ir cells, and percent of GnIH-Ir cells that were positive for Fos-Ir, plasma insulin, leptin, estradiol, and progesterone concentrations).

The correlations among 90-min food intake and the other variables were not statistically significant (body weight, change in body 

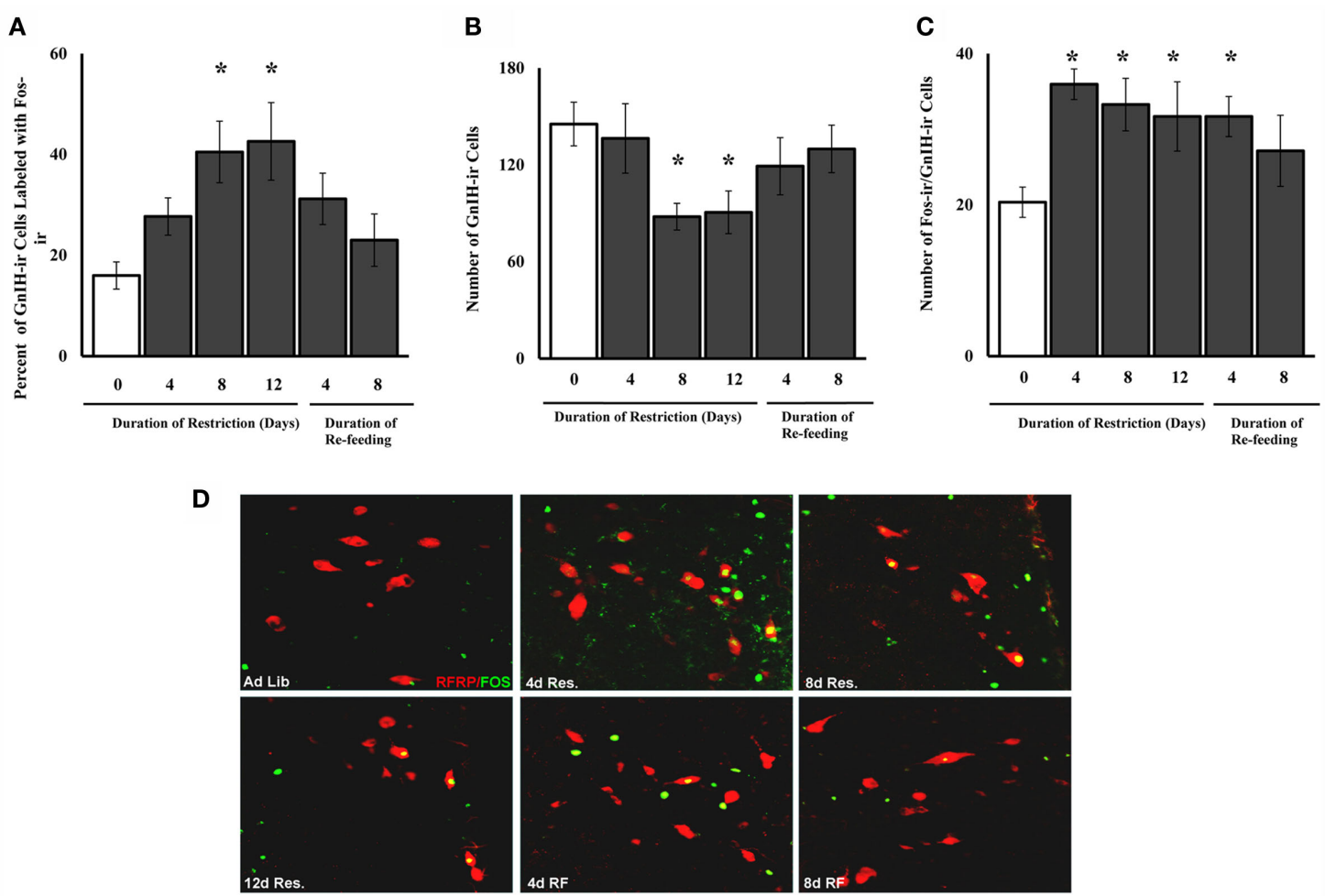

FIGURE 3 | Mean and SE of the mean for (A). the percent of $\mathrm{GnIH}-\mathrm{Ir}$ cells that showed Fos-Ir [(the number of double-labeled Fos-Ir and $\mathrm{GnIH}-\mathrm{Ir}$ cells divided by the total number of $\mathrm{GnIH}-\mathrm{Ir}$ cells) multiplied by 100], (B). the number of $\mathrm{GnIH-Ir}$ cells per animal (both Fos-Ir-labeled and unlabeled), (C). the absolute number of cells that were double-labeled for both Fos-Ir and $\mathrm{GnIH-Ir}$ in gonadally intact, female Syrian hamsters food-restricted for different durations, and (D). photomicrographs of cells double-labeled for GnIH-Ir (red) and Fos-Ir (green) following food restriction and re-feeding. Food-restricted females were fed $75 \%$ of their ad libitum intake for 4,8 , or 12 days or were food-restricted for 12 days and then re-fed for 4 or 8 days in Experiment 1. * Significantly different from ad libitum at $P<0.05$. weight, number of GnIH-Ir cells, or percent of GnIH-Ir cells that were positive for Fos-Ir, plasma insulin, estradiol, and progesterone concentrations).

There was a significant negative correlation between vaginal scent marks and cellular activation in GnIH-Ir cells $(r=-0.314$; $P<0.04)$ and a positive correlation between the number of vaginal scent marks and the number of cells that showed GnIH-Ir $(r=0.365 ; P<0.02)$. Vaginal scent marks were significantly negatively correlated with body weight loss; the more body weight lost, the fewer vaginal scent marks $(r=-0.619 ; P<0.0001)$, but vaginal scent marks were not significantly correlated with final body weight. Vaginal scent marks were also positively correlated with plasma progesterone concentrations $(r=0.354, P<0.02)$, but not with leptin, insulin, or estradiol concentrations.

There were no significant correlations between flank marks and any other variables (number of GnIH-Ir cells, cellular activation in GnIH-Ir cells, change in body weight, insulin, estradiol, or progesterone concentrations).

There was a significant negative correlation between male preference and change in body weight $(r=0.352 ; P<0.01)$, but the correlations between male preference and other variables were not statistically significant (body weight, number of GnIH-Ir cells, cellular activation in GnIH-Ir cells, plasma leptin, insulin, estradiol, or progesterone concentrations).
There was a significant positive correlation between body weight and plasma progesterone concentrations $(r=0.302$; $P<0.04)$ and between body weight and plasma leptin concentrations $(r=0.285 ; P<0.05)$, but not between body weight and plasma insulin or estradiol concentrations. Body weight was not significantly correlated with either the number of $\mathrm{GnIH}$ cells, or the percent of GnIH-Ir cells that were positive for Fos. Change in body weight was significantly positively correlated with plasma progesterone concentrations $(r=0.451 ; P<0.001)$ and the number of GnIH-Ir cells $(r=0.459 ; P<0.002)$ and significantly negatively correlated with the percent of GnIH-Ir cells that were positive for Fos- $\mathrm{Ir}(\mathrm{r}=0.570 ; P<0.0001)$.

\section{EXPERIMENT 2: EFFECT OF METABOLIC CHALLENGES ON NPY FIBERS IN THE DMH}

In Experiment 2A, females with either high or low body weight were either fed ad libitum or food-deprived for $72 \mathrm{~h}$ from day 1 to day 4 of the estrous cycle (Figure 5). Previous work showed that the lean, food-deprived females would become anestrus, whereas those that were fat at the start of deprivation would be buffered from the effects of deprivation (Schneider and Wade, 1989, 1990). Two-way ANOVA showed a significant main effect of food deprivation on final body weight, with lean females weighing less than fat $[\mathrm{F}(1,6)=9.78, P<0.02]$. Post hoc analysis showed 

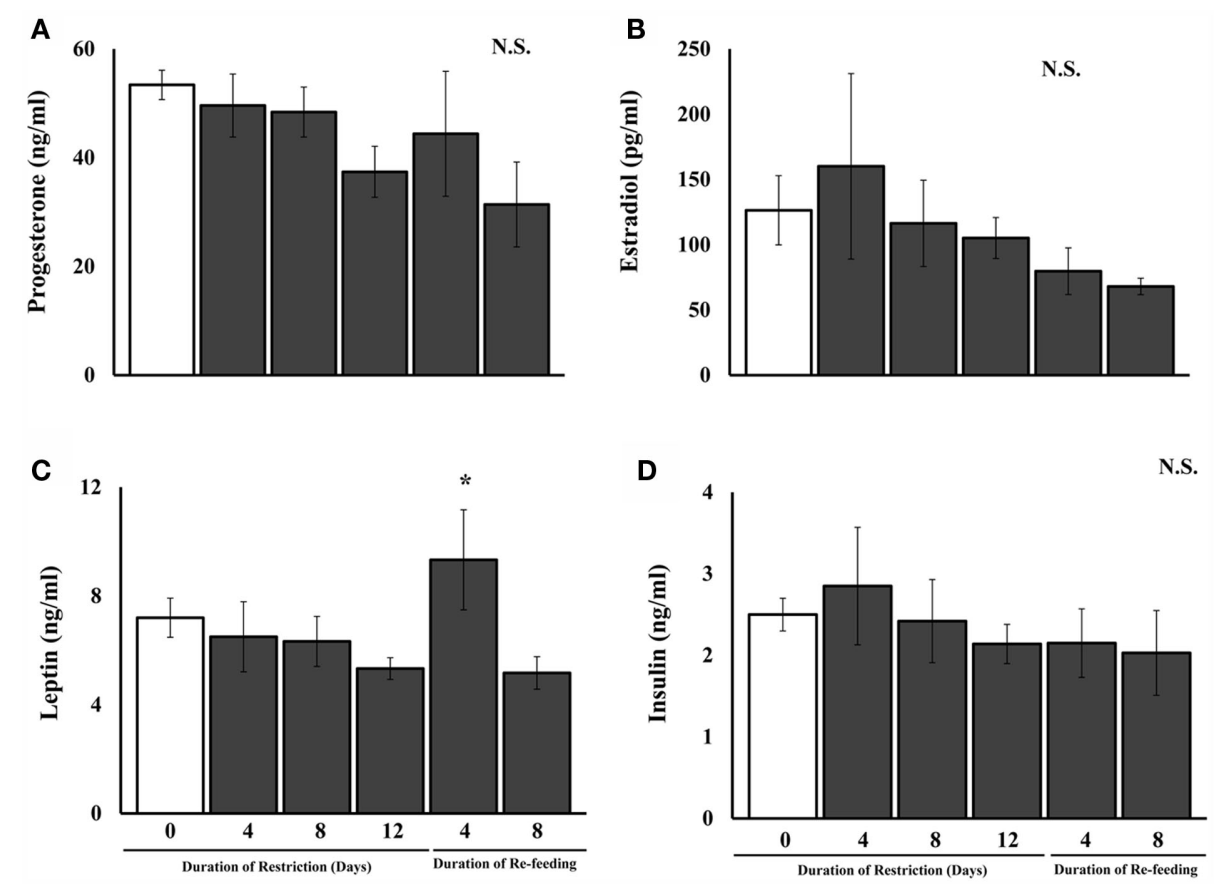

FIGURE 4 | Mean and SE of the mean for plasma concentrations of (A). progesterone, (B). estradiol, (C). leptin, and (D). insulin in female Syrian hamsters either fed ad libitum or food-restricted to $75 \%$ of their ad libitum

intake at 4,8 , or 12 days after the start of food restriction or after 12 days of restriction and either 4 or 8 days of re-feeding in Experiment 1 . * Significantly different from ad libitum at $P<0.05$.

that food-deprived lean females weighed significantly less than food-deprived, fat females $(P<0.05)$. The same analysis of the change in body weight over the course of food deprivation showed a significant main effect of food deprivation $[F(1,6)=49.51$, $P<0.0004$ ]. Two-way ANOVA showed a significant main effect of food deprivation on the percent of GnIH-Ir cells that were positive for Fos-Ir $[F(1,6)=7.69, P<0.03]$, no significant effect of body weight group, and no significant interaction. The more body weight lost, the higher the increase in percent of GnIH-Ir cells that were positive for Fos-Ir, and this correlation was significant ( $r=0.72, P<0.02$ ). Body weight loss was significantly negatively correlated with the number of cells that were immunoreactive for GnIH $(r=0.72, P<0.02)$. Neither the percent of GnIH-Ir cells positive for Fos-Ir nor the number of GnIH-Ir cells was significantly correlated with final body weight. There was a significant main effect of food deprivation or ad libitum feeding on plasma LH concentrations $[F(2,4)=16.217, P<0.01]$. As expected, the lean, food-deprived females had plasma $\mathrm{LH}$ concentrations significantly lower $(0.04 \pm 0.0001 \mathrm{ng} / \mathrm{ml})$ than the fat, food-deprived $(0.131 \pm 0.2 \mathrm{ng} / \mathrm{ml})$ and the ad libitum-fed control females (fat and lean combined $0.205 \pm 0.038 \mathrm{ng} / \mathrm{ml}$ ).

In Experiment 2B, females were sacrificed after either 1.5 or 2.5 days of food deprivation during the follicular phase of the estrous cycle (Days 1 and 2 of the estrous cycle) to determine whether there were changes in $\mathrm{GnIH}$ that occur in the early stages of metabolic challenge that would be expected to inhibit the GnRH pulse generator in lean, but not fat females (Morin, 1986). One-way ANOVA showed no significant effect of treatment group on the percent of GnIH-Ir cells that were positive for Fos-Ir, and a significant effect of treatment group on the number of GnIH-Ir

cells $[F(2,16)=27.95, P<0.0001$; Table 2]. Both food-deprived groups (30 and $50 \mathrm{~h}$ of deprivation) had significantly fewer $\mathrm{GnIH}$ Ir cells than did the ad libitum-fed controls $(P<0.0001)$. The percent of GnIH-Ir cells that were positive for Fos-Ir increased linearly with the amount of body weight loss and this correlation was significant $(r=0.62, P<0.004)$. This variable was also significantly positively correlated with final body weight $(r=0.576$, $P<0.01)$. The number of GnIH-Ir cells was also significantly negatively correlated with the amount of body weight lost $(r=-0.58$, $P<0.01)$ and with final body weight $(r=-0.59, P<0.01)$.

Double-labeling for GnIH-Ir and NPY-Ir revealed that NPY-Ir nerve fibers were densely packed in the $\mathrm{DMH}$, and that putative NPY terminals can be observed in close proximity to $\mathrm{GnIH}$ cell bodies within this brain area (Figure 7) at low power light microscopy and confirmed at high power light microscopy and confocal microscopy. An average of $41.46 \%$ GnIH-Ir cell bodies per animal $(n=6)$ receive contacts from NPY-Ir fibers in the DMH.

\section{Discussion}

These experiments showed the following: (1) There was a linear effect of energy availability (duration of food restriction) on ingestive and sex behavior in Syrian hamsters, (2) mechanisms that control motivation were more sensitive to energy availability than mechanisms that control the performance of eating and copulation, (3) there was a linear effect of energy availability on the number of GnIH-Ir cells and on cellular activation in GnIHIr cells in the DMH, (4) cellular activation in GnIH-Ir cells was positively correlated with food hoarding and negatively correlated with vaginal scent marking, (5) GnIH-Ir cell number was 
Table 2 | Mean and SEM for body weight, change in body weight, percent of GnIH-Ir cells double-labeled for Fos, and the number of GnIH cells in Syrian hamsters from Experiment 2B. Hamsters were sacrificed in the early follicular phase of the estrous cycle just 36 or $50 \mathrm{~h}$ after the start of food deprivation on the morning of day 1 of the estrous cycle to determine whether there might be changes in GnIH cells that would predict reproductive states at the time of the LH surge that would be expected to occur on day 4 of the estrous cycle. Anestrous was expected to occur only in lean food deprived females.

\begin{tabular}{|c|c|c|c|c|c|}
\hline & \multirow[t]{2}{*}{ Ad libitum } & \multicolumn{2}{|c|}{ Fat, food-deprived } & \multicolumn{2}{|c|}{ Lean, food-deprived } \\
\hline & & $36 \mathrm{~h}$ & $50 \mathrm{~h}$ & $36 \mathrm{~h}$ & $50 \mathrm{~h}$ \\
\hline$\Delta$ Body weight (g) & $-0.03 \pm 0.5$ & $-5.6 \pm 0.6^{*}$ & $-12.2 \pm 1.0^{*}$ & $-5.4 \pm 0.2^{*}$ & $-14.6 \pm 1.5^{*}$ \\
\hline$\% \mathrm{FOS}+\mathrm{GnIH}$ & $24.5 \pm 3.3$ & $32.3 \pm 6.7$ & $34.3 \pm 4.2$ & $35.3 \pm 3.8$ & $48.6 \pm 8.9$ \\
\hline GnlH-ir & $122.6 \pm 9.9$ & $24.1 \pm 5.1^{*}$ & $38.0 \pm 5.2^{*}$ & $48.7 \pm 11.6^{*}$ & $36.8 \pm 15.3^{*}$ \\
\hline
\end{tabular}

${ }^{*}$ Significantly different from ad libitum-fed at $P<0.05$

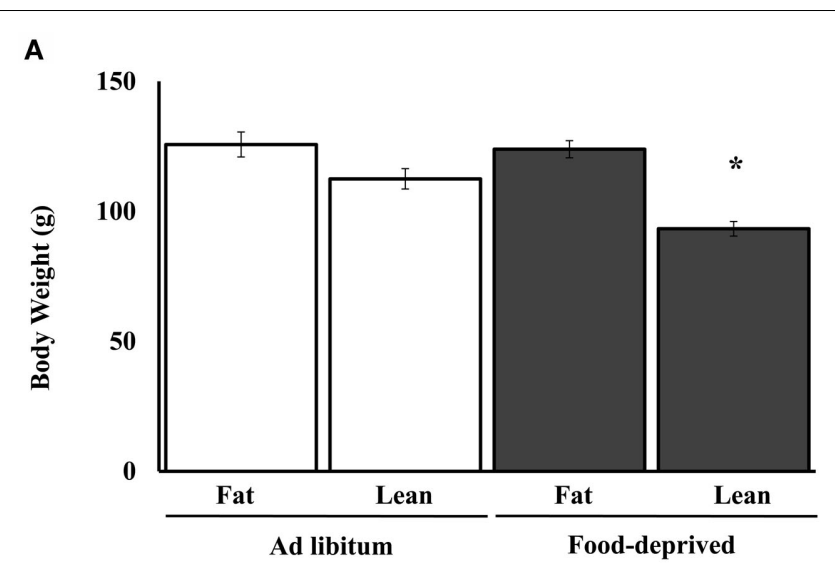

B

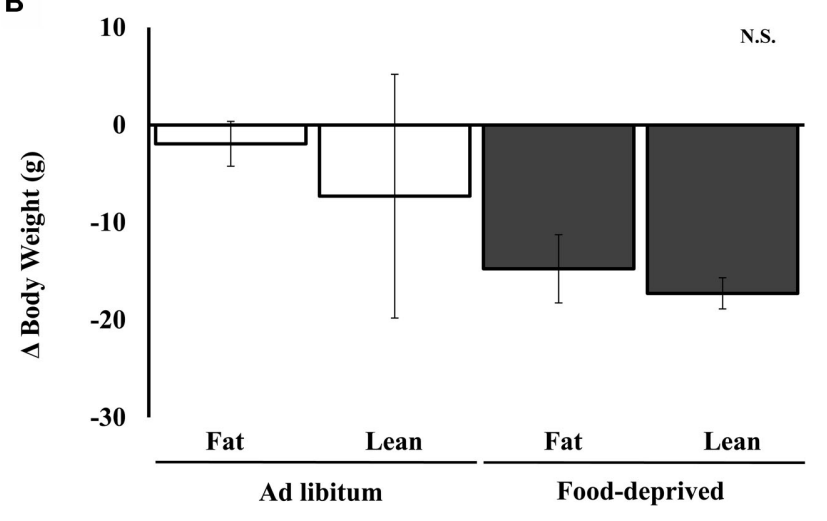

FIGURE 5 | Mean and SE of the mean for (A). body weight of ad libitum-fed or food-deprived female hamsters that were lean or fat prior to the start of food deprivation and $(\mathbf{B})$. change in body weight of the same females after food deprivation in Experiment 2A. * Significantly different from ad libitum at $P<0.05$.

negatively correlated with food hoarding and positively correlated with vaginal scent marking, (6) there was no significant effect of food restriction on plasma leptin, insulin, estradiol, or progesterone concentrations and no significant correlation among hormone concentrations and cellular activation of GnIH-Ir cells, and (7) strong projections of NPY-Ir fibers were found in close apposition to $\mathrm{GnIH}$-containing cell bodies in the DMH. Together these results are consistent with the idea that a wide range of metabolic deficits have effects on the GnIH system that are significantly correlated with changes in motivation. These effects on cellular activation in GnIH-Ir cells occurred in females that showed normal circulating levels of ovarian steroids, i.e., females that were not hypogonadotropic. Furthermore, projections from NPY-Ir cells to $\mathrm{GnIH}$ cells in the DMH are one possible route of transmission of information about energy availability to the GnIH system.

By using mild levels of food restriction at different durations, we were able to dissociate appetitive from consummatory behaviors. Appetitive, but not consummatory behaviors were affected by shorter durations of food restriction. This, in turn, enabled the investigation of neuroanatomical correlates. Food hoarding and vaginal scent marking were significantly affected at 8 and 12 days of $25 \%$ food restriction, even though there was no effect on the consummatory behavior, food intake (Figures 1 and 2). Mild food restriction did not lead to significant decreases in circulating levels of estradiol and progesterone (Figures 4A,B), confirming that estrous cycles were not disrupted. The body weight, age and level of food restriction were chosen for these experiments because two previously published experiments showed that, under these conditions, estrous cycles were not disrupted and females showed no deficits in lordosis frequency or duration (Klingerman et al., 2010, 2011). Changes in cellular activation in GnIH-Ir cells in non-hypogonadotropic Syrian hamsters suggests that this peptide plays a role in control of behavioral motivation, rather than or in addition to control of the HPG system.

The most striking and unexpected observation was the close correlation between cellular activation in GnIH-Ir cells and the change in appetitive behaviors seen in mildly food-restricted females in Experiment 1 (Figure 3). Just as the appetitive behaviors (food hoarding and vaginal scent marking) showed significant changes at 8 and 12 days after restriction, cellular activation in GnIH-Ir cells also increased at these same time points. Restoration of food hoarding and Fos/GnIH-Ir to baseline levels occurred at the same time after re-feeding (Figures 1 and 3). In contrast to vaginal scent marking, flank marking was not significantly correlated with changes in cellular activation in GnIH-Ir cells or number of GnIH-Ir cells. Thus, the correlation was between neural activation in GnIH-Ir cells and appetitive ingestive and sex 
behavior, rather than between $\mathrm{GnIH}$ and agonistic social behavior. There was also no correlation between activation in GnIH-Ir cells and consummatory behaviors.

An unexpected finding was that in Experiment 2A, lean and fat food-deprived (in contrast to mildly food-restricted) females differed significantly in their body weight and plasma LH concentrations, but did not differ in cellular activation in GnIH-Ir cells (Figures 5A and 6B). Lean, but not fat, food-deprived females were expected to become anestrus based on previously published data (Schneider and Wade, 1989, 1990). Consistent with this prediction, the lean, food-deprived females had lower mean LH levels than fat, food-deprived females, yet both groups showed significant increases in cellular activation in GnIH-Ir (Figures 6B,C). Thus, it is possible that in Syrian hamsters, GnIH has important effects on behavioral motivation (Figure 1) without inhibition of LH secretion.

Food restriction significantly increased the number of Fospositive GnIH-Ir cells as well as the percent of the total GnIH-Ir cells that were Fos-positive. Food restriction did not significantly increase the number of GnIH-Ir cells, and, in some groups, decreased the number GnIH-Ir cells (Figures 3B and 6A). The increase in the number of activated GnIH-Ir cells coupled with a decreased number of GnIH-Ir cells might reflect increased GnIH release without a compensatory increase in $\mathrm{GnIH}$ synthesis. There is precedence in the literature for a decrease in cell number concomitant with an increase in cellular activation and release of peptide. For example, gonadatropin releasing-hormone $(\mathrm{Gn} R \mathrm{H})$ Ir cells in rats also decrease in number during the latter part of the LH surge when the number and percent of Fos-Ir/GnRHIr double-labeled cells increases (Lee et al., 1990). In addition, a different environmental factor, short day length, also causes a decrease in GnIH-Ir cell number along with gonadal regression and inhibition of LH secretion (Kriegsfeld et al., 2010). Perhaps if we had sacrificed the hamsters earlier, the GnIH-Ir cell population might have remained stable in number. This could be confirmed by examination of GnIH-Ir at earlier time points, by examination of GnIH-Ir in hamsters treated with agents that block axon transport, and by measuring $\mathrm{GnIH}$ gene expression using in situ hybridization.

Another possibility is that increased cellular activation along with the observed decrease in the total number of GnIH-Ir cells represents inhibition of $\mathrm{GnIH}$ synthesis and secretion. This $\mathrm{s}$ unlikely because the decrease in cell number in this experiment did not occur in all experimental groups (for example the 4-day foodrestricted group; Figure 3B), and there was a significant increase in double-labeled cells in all food-restricted females (Figure 3C; not just an increase in the percent of cells). As mentioned in an earlier paragraph, however, exposure of hamsters to short day length decreases GnIH-Ir cell number under circumstances in which increases in $\mathrm{GnIH}$ secretion appear to underlie inhibition of $\mathrm{LH}$ secretion and gonadal regression (Kriegsfeld et al., 2010).

The decrease in GnIH-Ir cell number, along with an increase in the percent of GnIH cells that were activated closely correlated with behavioral motivation might be a reflection of a subpopulation of cells that is particularly responsive to energy availability. Evidence in other species suggests that KiSS-1 and GnIH act together to coordinate the effects of day length and food availability. KiSS-1 expression increases with food restriction in Siberian hamsters (Paul et al., 2009), is associated with increased GnRH and LH secretion, and has been located in the DMH of rats (Brailoiu et al., 2005). It is not known whether there are KiSS-1-containing cells in the Syrian hamster DMH or sites that project to the DMH. Furthermore, GnIH and KiSS-1 might be implicated in both circadian and seasonal rhythms related to energy balance and reproduction in hamsters. For example, DMH lesions block the effects of short day length on the HPG system in Syrian hamsters. The suprachiasmatic nucleus (SCN) projects to a large proportion of GnIH cells in the $\mathrm{DMH}$, and these project to the vicinity of GnRH cells. Thus, it is plausible that information from peripheral or central oscillators are influenced by metabolic fuel availability and project to the SCN, which, in turn, might influence GnIH, KiSS-1 or other cells in the DMH. Other investigators have suggested that the DMH itself receives information generated by the ingestion of meals in mice and rats (Gooley et al., 2006; Fuller et al., 2008), although other evidence contradicts the idea that the DMH is necessary for meal entrainment of circadian rhythms in rats and mice (Landry et al., 2006, 2007; Moriya et al., 2009).

Food restriction in Experiment 1 and food deprivation in Experiment 2A had significant effects on both cellular activation and on number of GnIH-Ir cells, but it is not clear how this information about food availability reaches the DMH. Food restriction, for example, had significant effects on appetitive behaviors without significant effect on plasma concentrations of ovarian steroids, insulin, or leptin, suggesting that information about fuel availability reaches $\mathrm{GnIH}$ cells via other means, e.g., via changes in plasma ghrelin or direct information about the availability of oxidizable metabolic fuels detected in periphery, brain stem or hypothalamic areas that project to $\mathrm{GnIH}$ cells.

One possibility is that GnIH cells in food-restricted females are more responsive to estradiol than those $\mathrm{GnIH}$ cells in females fed ad libitum. As expected, there were no significant food restrictioninduced decreases in plasma estradiol concentrations, even in groups that showed food restriction-induced changes in sex and ingestive behavior (Figure 4). Thus, one possible explanation is up-regulation of ER on GnIH cells that project to areas involved in ingestive behavior and a down-regulation of ER in areas involved in sex behavior. A similar suggestion has been made regarding upregulation of ER in other brain areas involved ingestive behavior $(\mathrm{PVH})$ and a down-regulation of ER in brain areas involved in lordosis (VMH; Li et al., 1994; Panicker et al., 1998). The DMH and appetitive behaviors were not examined in these latter studies. However, ER- $\alpha$ co-localizes with GnIH cells in the Syrian hamsters $\mathrm{DMH}$, and these cells respond to estradiol stimulation with significant increases in cellular activation (Kriegsfeld et al., 2006). Thus, future experiments will determine whether different levels of food restriction (mild to severe) down-regulates ER- $\alpha$ in GnIH cells in the $\mathrm{DMH}$, or whether the effects of food restriction might occur downstream or independent from ER- $\alpha$-containing GnIH cells.

One such downstream mediator might be GnRH. Midbrain $\mathrm{GnRH}$ and its metabolites have well-documented facilitatory effects on sex behavior that are unrelated to LH secretion (Moss and McCann, 1975; Moss and Foreman, 1976; Dudley et al., 1981; Dudley and Moss, 1988, 1991; Moss and Dudley, 1990; Wu et al., 2006). It is plausible that GnIH-mediated inhibition of $\mathrm{GnRH}$ 

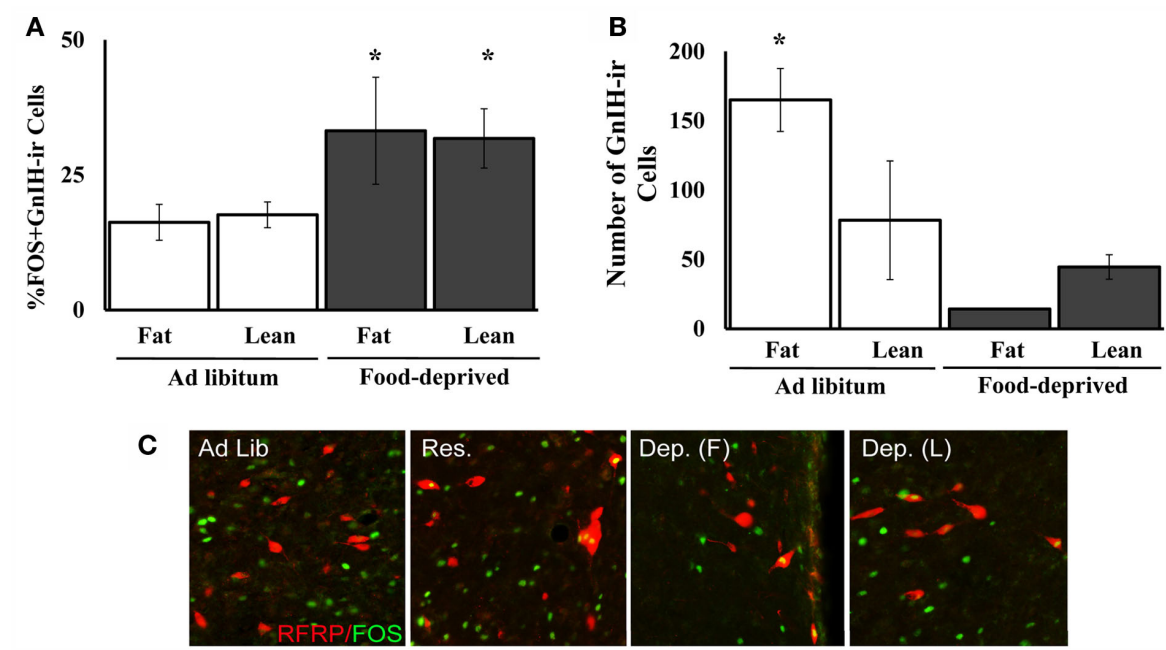

FIGURE 6 | Mean and SE of the mean for (A). the percent of GnlH-Ir cells double-labeled for Fos-Ir in the $\mathrm{DMH}$ and $(\mathbf{B})$. the number of GnIH-Ir cells (both Fos-Ir-labeled and unlabeled) in the DMH of female Syrian hamsters that were food-deprived or fed ad libitum, and half of the secretion accounts for inhibition of appetitive sex behavior in Syrian hamsters. Furthermore, the appetitive ingestive behavior, food hoarding, was significantly increased in the present experiment, consistent with mounting evidence that ingestive behaviors are increased by GnIH (Tachibana et al., 2005; Johnson et al., 2007). GnIH inhibits GnRH secretion in Syrian hamsters (Kriegsfeld et al., 2006), and at least one form of GnRH (GnRH-II) is inhibitory for ingestive behavior (Kauffman, 2004; Kauffman and Rissman, 2004a,b; Kauffman et al., 2005).

A large body of research implicates NPY in metabolic control of reproduction and ingestive behavior. NPY is a potent orexigenic peptide (Clark et al., 1984; Kulkosky et al., 1988; Corp et al., 2001; Clarke et al., 2005), inhibits sex behavior (Clark et al., 1985; Thornton et al., 1996), and inhibits LH secretion in the presence of low circulating levels of estradiol (Khorram et al., 1987; Sahu et al., 1987; Malven et al., 1992). NPY has greater effects on appetitive than consummatory behaviors (Ammar et al., 2000; Day et al., 2005; Keen-Rhinehart and Bartness, 2007). Furthermore, NPY cell bodies in the DMH and other brain areas have long been implicated in control of energy intake. NPY mRNA is overexpressed in the DMH during the hyperphagia of lactation (Smith, 1993) and in various models of obesity (Kesterson et al., 1997; Guan et al., 1998a,b; Tritos et al., 1998). Increases in NPY gene expression in the DMH of lean rats increases food intake and body weight, and accelerates the development of high-fat diet-induced obesity, and decreased NPY expression in the DMH prevents the hyperphagia, obesity and diabetes of Otsuka Long-Evans Tokushima Fatty rats (Yang et al., 2009). Thus, we were compelled to examine the proximity of NPY projections to GnIH cells in the DMH. Fooddeprived females were used to maximize identification of NPY cells. NPY terminals showed strong projections to the DMH and were seen in close apposition to GnIH cells (Figure 7). It is possible that these NPY cells originate in the arcuate nucleus of the hypothalamus, the brain stem, or from within the $\mathrm{DMH}$, all areas where NPY gene expression has been identified and from which food-deprived hamsters were lean and the other half were fattened prior to the start of food deprivation in Experiment 2A. (C). Photomicrographs of $\mathrm{GnIH/Fos-Ir}$ in the groups described. *Significantly different from ad libitum at $P<0.05$.

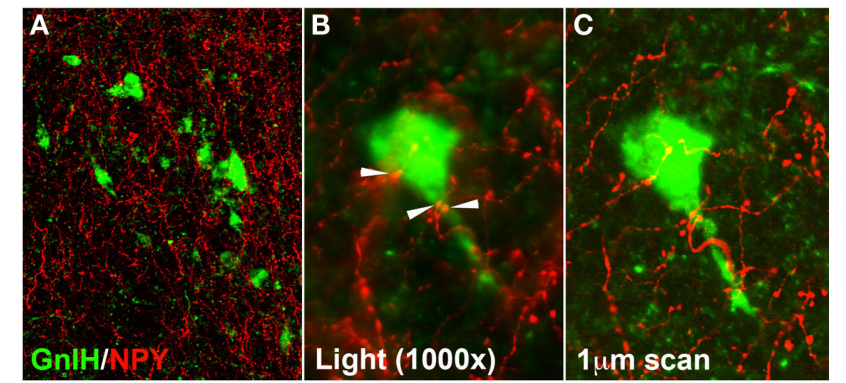

FIGURE 7 | Representative photomicrographs of cells double-labeled for GnIH (red) and NPY (green). A cluster of GnlH-r cells receive extensive NPY projections at $250 \times$ in this confocal scan (A) and a single $\mathrm{GnlH}$-Ir cell with presumptive NPY boutons at $1000 \times$ at the conventional (B) and confocal (C) microscopic levels.

NPY cells project to the DMH in other rodents (Bai et al., 1985; Sahu et al., 1988; Bi et al., 2003).

In summary, these results show a clear correlation between cellular activation in GnIH-Ir cells and appetitive sex and ingestive behaviors. It is not known, however, whether $\mathrm{GnIH}$ secretion causes changes in motivation. GnIH might be a causal factor for increased hunger and food hoarding, decreased sexual motivation, or both, but it might be a non-functional correlate of other causal factors (metabolic events, other hormones, and other neuropeptides such as kisspeptin, NPY, alpha-melanocyte stimulating hormone or orexin). GnRH, for example, might influence ingestive and sex behavior by virtue of its direct link to metabolic cues, since recent evidence shows that $\mathrm{GnRH}$ neurons receive dendritic input from outside the blood-brain barrier (Herde et al., 2011). Further work is necessary to determine whether changes in GnIH cells are a fortuitous correlate or a causal factor in control of behavior. Nevertheless, these results are consistent with the idea that GnIH 
in the DMH, and possibly NPY cells that project to the DMH are part of a system that prioritizes sex and ingestive behavior in order to optimize reproductive success in environments where energy availability fluctuates. Current experiments are underway to examine if central or systemic treatment with GnIH, NPY, and antagonists to their receptors have the expected influences on appetitive and consummatory sex and ingestive behavior in Syrian hamsters.

\section{REFERENCES}

Ahima, R. S., Prabakaran, D., Mantzoros, C., Qu, D., Lowell, B., Maratos-Flier, E., and Flier, J. S. (1996). Role of leptin in the neuroendocrine response to fasting. Nature 382, 250-252.

Albers, H. E., and Rawls, S. (1989). Coordination of hamster lordosis and flank marking behavior: role of arginine vasopressin within the medial preoptic-anterior hypothalamus. Brain Res. Bull. 23, 105-109.

Albers, H. E., and Rowland, C. M. (1989). Ovarian hormones influence odor stimulated flank marking behavior in the hamster (Mesocricetus auratus). Physiol. Behav. 45, 113-117.

Ammar, A. A., Sederholm, F., Saito, T. R., Scheurink, A. J., Johnson, A. E., and Sodersten, P. (2000). NPYleptin: opposing effects on appetitive and consummatory ingestive behavior and sexual behavior. Am. J. Physiol. Regul. Integr. Comp. Physiol. 278, R1627-R1633.

Anderson, G. M., Relf, H. L., Rizwan, M. Z., and Evans, J. J. (2009). Central and peripheral effects of RFamiderelated peptide- 3 on luteinizing hormone and prolactin secretion in rats. Endocrinology 150, 1834-1840.

Armstrong, J. D., and Britt, J. H. (1987). Nutritionally-induced anestrus in gilts: metabolic and endocrine changes associated with cessation and resumption of estrous cycles. J. Anim. Sci. 65, 508-523.

Bai, F. L., Yamano, M., Shiotani, Y., Emson, P. C., Smith, A. D., Powell, J. F., and Tohyama, M. (1985). An arcuato-paraventricular and -dorsomedial hypothalamic neuropeptide Y-containing system which lacks noradrenaline in the rat. Brain Res. 331, 172-175.

Bentley, G. E., Jensen, J. P., Kaur, G. J., Wacker, D. W., Tsutsui, K., and Wingfield, J. C. (2006). Rapid inhibition of female sexual behavior by gonadotropin-inhibitory hormone (GnIH). Horm. Behav. 49, 550-555.

Bentley, G. E., Tsutsui, K., and Kriegsfeld, L. J. (2010). Recent studies of gonadotropin-inhibitory hormone (GnIH) in the mammalian hypothalamus, pituitary and gonads. Brain Res. 1364, 62-71.

Bi, S., Robinson, B. M., and Moran, T. H. (2003). Acute food deprivation and chronic food restriction differentially affect hypothalamic NPY mRNA expression. Am. J. Physiol. Regul. Integr. Comp. Physiol. 285, R1030-R1036.

Brady, L. S., Smith, M. A., Gold, P. W., and Herkenham, M. (1990). Altered expression of hypothalamic neuropeptide mRNAs in food-restricted and food-deprived rats. Neuroen-

Brailoiu, G. C., Dun, S. L., Ohsawa, M., Yin, D., Yang, J., Chang, J. K., Brailoiu, E., and Dun, N. J. (2005). KiSS-1 expression and metastin-like immunoreactivity in the rat brain. J. Comp. Neurol. 481, 314-329.

Bronson, F. H. (1986). Food-restricted, prepubertal, female rats: rapid recovery of luteinizing hormone pulsing with excess food, and full recovery of pubertal development with gonadotropin-releasing hormone. Endocrinology 118, 2483-2487.

Bronson, F. H. (1988). Effect of food manipulation on the GnRH-LHestradiol axis of young female rats. Am. J. Physiol. 254, R616-R621.

Bronson, F. H. (1989). Mammalian Reproductive Biology. Chicago: The University of Chicago Press.

Bronson, F. H., and Marsteller, F. A. (1985). Effect of short-term food deprivation on reproduction in female mice. Biol. Reprod. 33, 660-667.

Cameron, J. L. (1996). Regulation of reproductive hormone secretion in primates by short-term changes in nutrition. Rev. Reprod. 1, 117-126.

Clark, J. T., Kalra, P. S., Crowley, W. R., and Kalra, S. P. (1984). NPY and human pancreatic polypeptide stimulate feeding behavior in rats. Endocrinology 115, 427-429.

Clark, J. T., Kalra, P. S., and Kalra, S. P. (1985). Neuropeptide Y stimulates feeding but inhibits sexual behavior in rats. Endocrinology 117, 2435-2442. docrinology 52, 441-447.

\section{ACKNOWLEDGMENTS}

This work was supported in part by IBN0645882 from the National Science Foundation (Jill E. Schneider) and the National Institutes of Health Grant HD 050470 (Lance J. Kriegsfeld). The authors would like to thank Jen Golley for technical assistance and Jeremy Brozek, Noah Benton, Jessica Sevetson, Millie Shah, Elizabeth Krumm, Kelsy Stocker, and Elise Esposito for their patient and thorough proof reading the manuscript.

Clarke, I. J., Backholer, K., and Tilbrook, A. J. (2005). Y2 receptorselective agonist delays the estrogeninduced luteinizing hormone surge in ovariectomized ewes, but $\mathrm{y} 1$ receptor-selective agonist stimulates voluntary food intake. Endocrinology 146, 769-775.

Clarke, I. J., Sari, I. P., Qi, Y., Smith, J. T., Parkington, H. C., Ubuka, T., Iqbal, J., Li, Q., Tilbrook, A., Morgan, K., Pawson, A. J., Tsutsui, K., Millar, R. P., and Bentley, G. E. (2008). Potent action of RFamide-related peptide- 3 on pituitary gonadotropes indicative of a hypophysiotropic role in the negative regulation of gonadotropin secretion. Endocrinology 149, 5811-5821.

Corp, E. S., Greco, B., Powers, J. B., Marin Bivens, C. L., and Wade, G. N. (2001). Neuropeptide Y inhibits estrous behavior and stimulates feeding via separate receptors in Syrian hamsters. Am. J. Physiol. Regul. Integr. Comp. Physiol. 280, R1061R1068.

Craig, W. (1917). Appetites and aversions as constituents of instinct. Proc. Natl. Acad. Sci. U.S.A. 3, 685-688.

Cunningham, M. J. (2004). Galanin-like peptide as a link between metabolism and reproduction. J. Neuroendocrinol. 16, 717-723.

Day, D. E., Keen-Rhinehart, E., and Bartness, T. J. (2005). Role of NPY and its receptor subtypes in foraging, food hoarding, and food intake by Siberian hamsters. Am. J. Physiol. Regul. Integr. Comp. Physiol. 289, R29-R36.

Dudley, C. A., and Moss, R. L. (1988). Facilitation of lordosis in female rats by CNS-site specific infusions of an LH-RH fragment, Ac-LH-RH-(510). Brain Res. 441, 161-167.

Dudley, C. A., and Moss, R. L. (1991). Facilitation of sexual receptivity in the female rat by C-terminal fragments of LHRH. Physiol. Behav. 50, 1205-1208.

Dudley, C. A., Vale, W., Rivier, J., and Moss, R. L. (1981). The effect of LHRH antagonist analogs and an antibody to LHRH on mating behavior in female rats. Peptides 2, 393-396.
Eckel, L. A. (2004). Estradiol: a rhythmic, inhibitory, indirect control of meal size. Physiol. Behav. 82, 35-41.

Everitt, B. J. (1990). Sexual motivation: a neural and behavioural analysis of the mechanisms underlying appetitive and copulatory responses of male rats. Neurosci. Biobehav. Rev. 14, 217-232.

Foster, D. L., Nagatani, S., Bucholtz, D. C., Tsukamura, H., Tanaka, T., and Maeda, K-I. (1998). "Links between nutrition and reproduction: signals, sensors and pathways controlling GnRH secretion," in Nutrition and Reproduction, eds W. Hansel and S. McCann (Baton Rouge, LA: LSU Press), 1-22.

Foster, D. L., and Olster, D. H. (1985). Effect of restricted nutrition on puberty in the lamb: patterns of tonic luteinizing hormone $(\mathrm{LH})$ secretion and competency of the LH surge system. Endocrinology 116, 375-381.

Fuller, P. M., Lu, J., and Saper, C. B. (2008). Differential rescue of light- and food-entrainable circadian rhythms. Science 320 , 1074-1077.

Gattermann, R., Johnston, R. E., Yigit, N., Fritzsche, P., Larimer, S., Ozkurt S., Neumann, K., Song, Z., Colak, E., Johnston, J., and Mcphee, M. E. (2008). Golden hamsters are nocturnal in captivity but diurnal in nature. Biol. Lett. 4, 253-255.

Gibson, E. M., Humber, S. A., Jain, S., Williams, W. P. III, Zhao, S., Bentley, G. E., Tsutsui, K., and Kriegsfeld, L. J. (2008). Alterations in RFamide-related peptide expression are coordinated with the preovulatory luteinizing hormone surge. Endocrinology 149, 4958-4969.

Gooley, J. J., Schomer, A., and Saper, C. B. (2006). The dorsomedial hypothalamic nucleus is critical for the expression of food-entrainable circadian rhythms. Nat. Neurosci. 9, 398-407.

Guan, X. M., Yu, H., Trumbauer, M., Frazier, E., Van Der Ploeg, L. H., and Chen, H. (1998a). Induction of neuropeptide $\mathrm{Y}$ expression in dorsomedial hypothalamus of 
diet-induced obese mice. Neuroreport 9, 3415-3419.

Guan, X. M., Yu, H., and Van Der Ploeg, L. H. (1998b). Evidence of altered hypothalamic proopiomelanocortin/neuropeptide $\mathrm{Y}$ mRNA expression in tubby mice. Brain Res. Mol. Brain Res. 59, 273-279.

Henry, B. A., Goding, J. W., Alexander, W. S., Tilbrook, A. J., Canny, B. J., Dunshea, F., Rao, A., Mansell, A., and Clarke, I. J. (1999). Central administration of leptin to ovariectomized ewes inhibits food intake without affecting the secretion of hormones from the pituitary gland: evidence for a dissociation of effects on appetite and neuroendocrine function. Endocrinology 140, 1175-1182.

Herde, M. K., Geist, K., Campbell, R. E., and Herbison, A. E. (2011). Gonadotropin-releasing hormone neurons extend complex highly branched dendritic trees outside the blood-brain barrier. Endocrinology 10, 3832-3841.

Hoffman, G. E., Lee, W. S., Smith, M. S., Abbud, R., Roberts, M. M., Robinson, A. G., and Verbalis, J. G. (1993). c-Fos and Fos-related antigens as markers for neuronal activity: perspectives from neuroendocrine systems. NIDA Res. Monogr. $125,117-133$.

I'anson, H., Foster, D. L., Foxcroft, C. R., and Booth, P. J. (1991). Nutrition and reproduction. Oxf. Rev. Reprod. Biol. 13, 239-311.

Johnson, M. A., Tsutsui, K., and Fraley, G. S. (2007). Rat RFamide-related peptide-3 stimulates GH secretion, inhibits LH secretion, and has variable effects on sex behavior in the adult male rat. Horm. Behav. 51, 171-180.

Johnston, R. E. (1974). Sexual attraction function of golden hamster vaginal secretion. Behav. Biol. 12, 111-117.

Johnston, R. E. (1977). The causation of two scent-marking behavior patterns in female hamsters (Mesocricetus auratus). Anim. Behav. $25,317-327$

Jones, J. E., Pick, R. R., Dettloff, S. L., and Wade, G. N. (2004). Metabolic fuels, neuropeptide $\mathrm{Y}$, and estrous behavior in Syrian hamsters. Brain Res. 1007, 78-85.

Kalra, S. P., Clark, J. T., Sahu, A., Dube, M. G., and Kalra, P. S. (1988). Control of feeding and sexual behaviors by neuropeptide Y: physiological implications. Synapse 2, 254-257.

Kaplan, J. M., Bednar, I., and Sodersten, P. (1992). Simultaneous display of sexual and ingestive behavior by rats. J. Neuroendocrinol. 4, 381-392.
Kauffman, A. S. (2004). Emerging functions of gonadotropin-releasing hormone II in mammalian physiology and behaviour. J. Neuroendocrinol. 16, 794-806.

Kauffman, A. S., and Rissman, E. F. (2004a). A critical role for the evolutionarily conserved gonadotropinreleasing hormone II: mediation of energy status and female sexual behavior. Endocrinology 145, 3639-3646.

Kauffman, A. S., and Rissman, E. F. (2004b). The evolutionarily conserved gonadotropin-releasing hormone II modifies food intake. Endocrinology 145, 686-691.

Kauffman, A. S., Wills, A., Millar, R. P., and Rissman, E. F. (2005). Evidence that the type-2 gonadotrophinreleasing hormone $(\mathrm{GnRH})$ receptor mediates the behavioural effects of GnRH-II on feeding and reproduction in musk shrews. J. Neuroendocrinol. 17, 489-497.

Keen-Rhinehart, E., and Bartness, T. J. (2007). NPY Y1 receptor is involved in ghrelin- and fastinginduced increases in foraging, food hoarding, and food intake. Am. J. Physiol. Regul. Integr. Comp. Physiol. 292, R1728-R1737.

Kesterson, R. A., Huszar, D., Lynch, C. A., Simerly, R. B., and Cone, R. D. (1997). Induction of neuropeptide $Y$ gene expression in the dorsal medial hypothalamic nucleus in two models of the agouti obesity syndrome. Mol. Endocrinol. 11, 630-637.

Khorram, O., Pau, K. Y., and Spies, H. G. (1987). Bimodal effects of neuropeptide $\mathrm{Y}$ on hypothalamic release of gonadotropin-releasing hormone in conscious rabbits. Neuroendocrinology 45, 290-297.

Klingerman, C. M., Krishnamoorthy, K., Patel, K., Spiro, A. B., Struby, C., Patel, A., and Schneider, J. E. (2010). Energetic challenges unmask the role of ovarian hormones in orchestrating ingestive and sex behaviors. Horm. Behav. 58, 563-574.

Klingerman, C. M., Patel, A., Hedges, V. L., Meisel, R. L., and Schneider, J. E. (2011). Food restriction dissociates sexual motivation, sexual performance, and the rewarding consequences of copulation in female Syrian hamsters. Behav. Brain Res. 223, 356-370.

Kriegsfeld, L. J. (2006). Driving reproduction: RFamide peptides behind the wheel. Horm. Behav. 50, 655-666.

Kriegsfeld, L. J., Gibson, E. M., Williams, W. P. III, Zhao, S., Mason, A. O., Bentley, G. E., and Tsutsui, K. (2010). The roles of
RFamide-related peptide- 3 in mammalian reproductive function and behaviour. J. Neuroendocrinol. 22 692-700.

Kriegsfeld, L. J., Mei, D. F., Bentley, G. E., Ubuka, T., Mason, A. O., Inoue, K., Ukena, K., Tsutsui, K., and Silver, R. (2006). Identification and characterization of a gonadotropin-inhibitory system in the brains of mammals. Proc. Natl. Acad. Sci. U.S.A. 103 , 2410-2415.

Kulkosky, P. J., Glazner, G. W., Moore, H. D., Low, C. A., and Woods, S. C. (1988). Neuropeptide Y: behavioral effects in the golden hamster. Peptides 9, 1389-1393.

Landry, G. J., Simon, M. M., Webb, I. C., and Mistlberger, R. E. (2006) Persistence of a behavioral foodanticipatory circadian rhythm following dorsomedial hypothalamic ablation in rats. Am. J. Physiol. Regul. Integr. Comp. Physiol. 290 R1527-R1534.

Landry, G. J., Yamakawa, G. R., and Mistlberger, R. E. (2007). Robust food anticipatory circadian rhythms in rats with complete ablation of the thalamic paraventricular nucleus. Brain Res. 1141, 108-118.

Lee, W.-S., Smith, M. S., and Hoffman, G. E. (1990). Luteinizing hormone-releasing hormone neurons express Fos protein during the proestrous surge of luteinizing hormone. Proc. Natl. Acad. Sci. U.S.A 87, 5163-5167.

Li, H. Y., Wade, G. N., and Blaustein, J. D. (1994). Manipulations of metabolic fuel availability alter estrous behavior and neural estrogen receptor immunoreactivity in Syrian hamsters. Endocrinology 135, 240-247.

Lisk, R. D., Ciaccio, L. A., and Catanzaro, C. (1983). Mating behavior of the golden hamster under seminatural conditions. Anim. Behav. 31, 659-666.

Lorenz, K. (1950). The comparative method in studying innate behavior patterns. Symp. Soc. Exp. Biol. 1950, 221-268.

Malven, P. V., Haglof, S. A., and Degroot, H. (1992). Effects of intracerebral administration of neuropeptide-Y on secretion of luteinizing hormone in ovariectomized sheep. Brain Res. Bull. 28, 871-875.

McClure, T. J. (1962). Infertility in female rodents caused by temporary inanition at or about the time of implantation. J. Reprod. Fertil. 4, 241.

McShane, T. M., May, T., Miner, J. L., and Keisler, D. H. (1992). Central actions of neuropeptide-Y may provide a neuromodulatory link between nutrition and reproduction. Biol. Reprod. 46, 1151-1157.

Morin, L. P. (1975). Effects of various feeding regimens and photoperiod or pinealectomy on ovulation in the hamster. Biol. Reprod. 13, 99-103.

Morin, L. P. (1986). Environment and hamster reproduction: responses to phase-specific starvation during estrous cycle. Am. J. Physiol. 251, R663-R669.

Moriya, T., Aida, R., Kudo, T., Akiyama, M., Doi, M., Hayasaka, N., Nakahata, N., Mistlberger, R., Okamura, H., and Shibata, S. (2009). The dorsomedial hypothalamic nucleus is not necessary for food-anticipatory circadian rhythms of behavior, temperature or clock gene expression in mice. Eur. J. Neurosci. 29, 1447-1460.

Moss, R. L., and Dudley, C. A. (1990). Differential effects of a luteinizing-hormone-releasing hormone (LHRH) antagonist analogue on lordosis behavior induced by LHRH and the LHRH fragment AcLHRH5-10. Neuroendocrinology 52, 138-142.

Moss, R. L., and Foreman, M. M. (1976). Potentiation of lordosis behavior by intrahypothalamic infusion of synthetic luteinizing hormone-releasing hormone. Neuroendocrinology 20, 176-181.

Moss, R. L., and McCann, S. M. (1975). Action of luteinizing hormonereleasing factor (lrf) in the initiation of lordosis behavior in the estroneprimed ovariectomized female rat. Neuroendocrinology 17, 309-318.

Panicker, A. K., Mangels, R. A., Powers, J. B., Wade, G. N., and Schneider, J. E. (1998). AP lesions block suppression of estrous behavior, but not estrous cyclicity, in food-deprived Syrian hamsters. Am. J. Physiol. 275, R158-R164.

Paul, M. J., Pyter, L. M., Freeman, D. A., Galang, J., and Prendergast, B. J. (2009). Photic and nonphotic seasonal cues differentially engage hypothalamic kisspeptin and RFamide-related peptide mRNA expression in Siberian hamsters. $J$. Neuroendocrinol. 21, 1007-1014.

Ronnekleiv, O. K., Ojeda, S. R., and Mccann, S. M. (1978). Undernutrition, puberty and the development of estrogen positive feedback in the female rat. Biol. Reprod. 19, 414-424. Sahu, A., Crowley, W. R., Tatemoto, K., Balasubramaniam, A., and Kalra, S. P. (1987). Effects of neuropeptide Y, NPY analog (norleucine4-NPY), galanin and neuropeptide $\mathrm{K}$ on $\mathrm{LH}$ release in ovariectomized (ovx) and ovx estrogen, progesterone-treated rats. Peptides 8, 921-926. 
Sahu, A., Kalra, S. P., Crowley, W. R., and Kalra, P. S. (1988). Evidence that NPY-containing neurons in the brainstem project into selected hypothalamic nuclei: implication in feeding behavior. Brain Res. 457, 376-378.

Schneider, J. E. (2004). Energy balance and reproduction. Physiol. Behav. 81, 289-317.

Schneider, J. E. (2006). Metabolic and hormonal control of the desire for food and sex: implications for obesity and eating disorders. Horm. Behav. 50, 562-571.

Schneider, J. E., Blum, R. M., and Wade, G. N. (2000). Metabolic control of food intake and estrous cycles in syrian hamsters. I. Plasma insulin and leptin. Am. J. Physiol. Regul. Integr. Comp. Physiol. 278, R476-R485.

Schneider, J. E., Casper, J. F., Barisich, A., Schoengold, C., Cherry, S., Surico, J., Debarba, A., and Rabold, E. (2007). Food deprivation and leptin prioritize ingestive and sex behavior without affecting estrous cycles in Syrian hamsters. Horm. Behav. 51, 413-427.

Schneider, J. E., Goldman, M. D., Tang, S., Bean, B., Ji, H., and Friedman, M. I. (1998). Leptin indirectly affects estrous cycles by increasing metabolic fuel oxidation. Horm. Behav. 33, 217-228.

Schneider, J. E., and Wade, G. N. (1989). Availability of metabolic fuels controls estrous cyclicity of Syrian hamsters. Science 244, 1326-1328.

Schneider, J. E., and Wade, G. N. (1990). Decreased availability of metabolic fuels induces anestrus in golden hamsters. Am. J. Physiol. 258, R750R755.

Shahab, M., Sajapitak, S., Tsukamura, H., Kinoshita, M., Matsuyama, S., Ohkura, S., Yamada, S., Uenoyama, Y., I'anson, H., and Maeda, K. (2006). Acute lipoprivation suppresses pulsatile luteinizing hormone secretion without affecting food intake in female rats. J. Reprod. Dev. 52, 763-772.

Shahab, M., Zaman, W., Bashir, K., and Arslan, M. (1997). Fasting-induced suppression of hypothalamicpituitary-gonadal axis in the adult rhesus monkey: evidence for involvement of excitatory amino acid neurotransmitters. Life Sci. 61, 1293-1300.

Sherrington, C. S. (1906). The Integrative Action of the Nervous System. New York: Scribner.

Smith, J. T., and Clarke, I. J. (2010). Gonadotropin inhibitory hormone function in mammals. Trends Endocrinol. Metab. 21, 255-260.

Smith, M. S. (1993). Lactation alters neuropeptide- $Y$ and proopiomelanocortin gene expression in the arcuate nucleus of the rat. Endocrinology 133, 1258-1265.

Smith, W. I., and Ross, S. (1950). Hoarding behavior in the golden hamster (Mesocricetus auratus auratus). J. Genet. Psychol. 77, 211-215.

Sokal, R. R., and Rohlf, F. J. (1969). Biometry: The Principles and Practice of Statistics in Biological Research. San Francisco: W. H. Freeman and Company.

Sprangers, S. A., and Piacsek, B. E. (1988). Increased suppression of luteinizing hormone secretion by chronic and acute estradiol administration in underfed adult female rats. Biol. Reprod. 39, 81-87.

Stanley, B. G., and Leibowitz, S. F. (1985). Neuropeptide Y injected in the paraventricular hypothalamus: a powerful stimulant of feeding behavior. Proc. Natl. Acad. Sci. U.S.A. 82, 3940-3943.

Szymanski, L. A., Schneider, J. E., Friedman, M. I., Ji, H., Kurose, Y., Blache, D., Rao, A., Dunshea, F. R., and Clarke, I. J. (2007). Changes in insulin, glucose and ketone bodies, but not leptin or body fat content precede restoration of luteinising hormone secretion in ewes. $J$. Neuroendocrinol. 19, 449-460.

Tachibana, T., Sato, M., Takahashi, H., Ukena, K., Tsutsui, K., and Furuse, M. (2005). Gonadotropininhibiting hormone stimulates feeding behavior in chicks. Brain Res. 1050, 94-100.

Temple, J. L., Schneider, J. E., Scott, D. K., Korutz, A., and Rissman, E.
F. (2002). Mating behavior is controlled by acute changes in metabolic fuels. Am. J. Physiol. Regul. Integr. Comp. Physiol. 282, R782-R790.

Terry, K. K., Chatman, L. A., Foley, G. L., Kadyszewski, E., Fleeman, T. L., Hurtt, M. E., and Chapin, R. E. (2005). Effects of feed restriction on fertility in female rats. Birth Defects Res. B Dev. Reprod. Toxicol. 74, 431-441.

Thomas, G. B., Mercer, J. E., Karalis, T., Rao, A., Cummins, J. T., and Clarke, I. J. (1990). Effect of restricted feeding on the concentrations of growth hormone $(\mathrm{GH})$, gonadotropins, and prolactin (PRL) in plasma, and on the amounts of messenger ribonucleic acid for $\mathrm{GH}$, gonadotropin subunits, and PRL in the pituitary glands of adult ovariectomized ewes. Endocrinology 126, 1361-1367.

Thornton, J. E., Holcomb, L., Leupen, S., and Kimbrough, L. (1996). Effects of neuropeptide Y (NPY) and NPY agonists on lordosis in the female Guinea pig. Endocrine 5, 169-177.

Tritos, N. A., Elmquist, J. K., Mastaitis, J. W., Flier, J. S., and Maratos-Flier, E. (1998). Characterization of expression of hypothalamic appetite-regulating peptides in obese hyperleptinemic brown adipose tissue-deficient (uncoupling protein-promoter-driven diphtheria toxin A) mice. Endocrinology 139, 4634-4641.

Tsutsui, K., Bentley, G. E., Bedecarrats, G., Osugi, T., Ubuka, T., and Kriegsfeld, L. J. (2010). Gonadotropin-inhibitory hormone (GnIH) and its control of central and peripheral reproductive function. Front. Neuroendocrinol. 31, 284-295.

Tsutsui, K., Saigoh, E., Ukena, K., Teranishi, H., Fujisawa, Y., Kikuchi, M., Ishii, S., and Sharp, P. J. (2000). A novel avian hypothalamic peptide inhibiting gonadotropin release. Biochem. Biophys. Res. Commun. 275, 661-667.

Waddell, D. (1951). Hoarding behavior in the golden hamster. J. Comp. Physiol. Psychol. 44, 383-388.
Wade, G. N., and Schneider, J. E. (1992). Metabolic fuels and reproduction in female mammals. Neurosci. Biobehav. Rev. 16, 235-272.

Wade, G. N., Schneider, J. E., and Friedman, M. I. (1991). Insulin-induced anestrus in Syrian hamsters. Am. J. Physiol. 260, R148-R152.

Wu, T. J., Glucksman, M. J., Roberts, J. L., and Mani, S. K. (2006). Facilitation of lordosis in rats by a metabolite of luteinizing hormone releasing hormone. Endocrinology 147, 2544-2549.

Yang, L., Scott, K. A., Hyun, J., Tamashiro, K. L., Tray, N., Moran, T. H., and Bi, S. (2009). Role of dorsomedial hypothalamic neuropeptide $\mathrm{Y}$ in modulating food intake and energy balance. J. Neurosci. 29, 179-190.

Conflict of Interest Statement: The authors declare that the research was conducted in the absence of any commercial or financial relationships that could be construed as a potential conflict of interest.

Received: 03 September 2011; accepted: 01 December 2011; published online: 27 December 2011.

Citation: Klingerman CM, Williams III WP, Simberlund J, Brahme N, Prasad A, Schneider JE and Kriegsfeld LJ (2011) Food restriction-induced changes in gonadotropin-inhibiting hormone cells are associated with changes in sexual motivation and food hoarding, but not sexual performance and food intake. Front. Endocrin. 2:101. doi: 10.3389/fendo.2011.00101

This article was submitted to Frontiers in Systems and Translational Endocrinology, a specialty of Frontiers in Endocrinology.

Copyright (C) 2011 Klingerman, Williams III, Simberlund, Brahme, Prasad, Schneider and Kriegsfeld. This is an open-access article distributed under the terms of the Creative Commons Attribution Non Commercial License, which permits non-commercial use, distribution, and reproduction in other forums, provided the original authors and source are credited. 